NBER WORKING PAPER SERIES

\author{
HOST-COUNTRY REGULATION AND OTHER \\ DETERMINANTS OF OVERSEAS OPERATIONS \\ OF U.S. MOTOR VEHICLE \\ AND PARTS COMPANIES
}

Ksenia Kulchycky

Robert E. Lipsey

Working Paper No. 1463

NATIONAL BUREAU OF ECONOMIC RESEARCH

1050 Massachusetts Avenue

Cambridge, MA 02138

September 1984

This paper was begun as part of a study of Multinational Firms and Host-Country Technology, supported by Grant No. 8017543 from the National Science Foundation to the NBER. Later work, particularly on the effects of host-country regulation, was done as part of the NBER's studies of U.S. Trade Policy, Competitiveness, and Capital Mobility in the World Economy (NSF Grant No. PRA-8116459). We are indebted to the Bureau of Economic Analys is of the U.S. Department of Commerce and particularly to George Kruer and Arnold Gilbert for access to calculations on the foreign investment data. Comments from Thomas Atkinson, John Barnes, William Long, Lee Price, Obie Whichard, and other participants in an NBER program meeting were also helpful. The research reported here is part of the NBER's research program in International Studies. Any opinions expressed are those of the authors and not those of the National Bureau of Economic Research or the National Science Foundation. 
NBER Working Paper \#1463 September 1984

Host-Country Regulation and Other Determinants of Overseas Operations of U.S. Motor Vehicle and Parts Companies

\section{ABSTRACT}

The likelihood that a U.S. auto company will carry out some manufacturing operations in a country is a function mainly of market characteristics such as aggregate and per capita income, but that likelihood is increased by the imposition of local content requirements. The entry of U.S. parts producers into manufacturing in a host country is determined mainly by market size and by the presence of U.S. auto producers and is therefore indirectly promoted by local content rules.

The scale of production by individual auto producers does not appear to be increased by a country's imposition of local content requirements and may even be reduced, with the results that inefficiently small operations proliferate. The scale of U.S. parts company production depends on market size and the extent of U.S. auto company activity.

The combination of induced entry of auto and parts producers with no effect or a negative effect on the scale of their individual operations suggests that countries imposing these restrictions do raise the aggregate level of local auto and parts production. However, they presumably pay some penalty in terms of sub-optimal scale and consequently high costs of production. 
host-Country Regulation and Other Determinants of Overseas Operations of U.S. Motor Vehicle and Parts Companies

\section{RESEARCH SUTMARY}

\section{Synopsis}

Issues: What factors have been responsible for the pattern of overseas location of production by U.S. auto and parts producers?

What have been the effects on location of local content and similar regulations imposed by host-country goversments?

Results: The dominant influences on location, given the long-standing institutional constraints that have tended to isolate markets in this industry, appear to have been economic rather than governmental. In particular, market size has been the main determinant of production location. However, local content requirements have had some effect on companies' location choices. They have pulled U.S. companies into producing in markets that some of them would have served from outside if they could. The regulations have tended to increase the number of U.S. auto companies producing in a market over what it would have been otherwise but have not encouraged larger-scale operations. They have probably tended to bring about fragmentation of markets and inefficiently small scales of operation. Parts producers' location decisions have not been directly influenced by these regulations but have been affected indirectly through the effects on auto company location.

\section{Policy Implications}

There has been much concern in the United States about the distortion of production decisions caused by local content and similar regulations. Aside from trade effects mentioned below, the subject of a later paper, the distortions of 
production decisions have probably been minor for the U.S. Industry, although they may have been large for some host countries. The main costs of these distortions have probably been borne by the consumers in the host countries themselves. By and large, given the long tradition in the industry of isolating markets through government actions, U.S. companies' production decisions have probably not been seriously distorted by the newer non-tariff forms of intervention.

\section{Further Research}

The data for the paper are, unfortunately, limited to the dates of U.S. direct investment surveys, the latest of which now avallable is for 1977. There is some possibility that the impact of host-country regulation has become more severe since then. This question should be investigated when the 1982 survey results become available for use.

This paper has not addressed the issue of distortions in trade, perhaps more severe than those in production and more objectionable to host countries' trading partners or potential partners. These questions will be discussed in a later paper from this study. 
I. Introduction

II. The Location of Overseas Manufacturing

a. General Factors in the Location of Multinational Firm Activities

b. The Segmentation of Motor Vehicle Markets

c. The Decision to Locate or Probability of Entry

III. Empirical Results

a. LOGIT Analysis of Location

b. The Level of Affiliate Activity

V. References 


\title{
HOST-COUNTRY REGULATION AND OTHER DETERMINANTS OF OVERSEAS \\ OPERATIONS OF U.S. MOTOR VEHICLE AND PARTS COMPANIES
}

\author{
Ksenia Kulchycky
}

Robert E. Lipsey

\section{INTRODUCTION}

The purpose of this paper is to study the determinants of the existence and size of manufacturing operations abroad by U.S. companies in the motor vehicle and parts industry. We analyze the influences that determined the location of various parts of the industry and in particular the way in which the location of these activities was affected by host-country regulations, such as domestic content requirements and subsidies.

The motor vehicle and parts industry is one of the most international of major U.S. manufacturing industry groups with respect to the location of its production activity. The number of employees in manufacturing operations abroad was higher than in any major industry group relative to U.S. employment in 1977, with almost as many employees overseas as in the United States (Table 1). The chemicals industry was the only close rival in this respect, with the pharmaceuticals subgroup even more international than motor vehicles. For manufacturing industries as a whole, employment in U.S.-owned operations in foreign countries was about a quarter of domestic employment.

Virtually every important company in the motor vehicle industry owns foreign manufacturing operations, although there are small segments of the industry, such as the manufacture of truck and bus bodies, which are not particularly international. As a result, parents of foreign subsidiaries make up almost the whole industry, while in other manufacturing 
Table 1

Comparison of Overseas Manufacturing Affiliate Employment ${ }^{a}$ with U.S. Domestic Employment, by Industry Group, 1977

\begin{tabular}{cclccc} 
& & & \multicolumn{2}{c}{ Parent Companies } \\
\cline { 3 - 5 } Foreign & Domestic & Foreign & Foreign & Domestic & Foreign as \\
Affiliate & Industry & as Per & Affiliate & Emplgy- & Per Cent \\
Emplof- & Employ- & Cent of & Employ- & ment & of Domest. \\
ment & ment & Domestic & ment & & Employ- \\
(Thous.of Employees) & Employm. (Thous.of & Employees) & ment \\
\hline
\end{tabular}

Total

Manufacturing

$$
4,855.1 \quad 19,443 \quad 25.0 \quad 5,322.9 \quad 11,775 \quad 45.2
$$

Foods, Tobacco

436.2

1,581

27.6

484.0

1,017

47.6

Chemicals

$$
614.1
$$

880

69.8

747.1

1,208

61.8

Metals

396.2

2,670

14.8

458.0

1,484

30.9

Nonelect. Mach.

627.4

2,083

30.1

762.5

1,546

49.3

Elect. Mach.

756.3

1,723

43.9

658.6

1,274

51.7

Transp. Equip.

909.8

1,768

51.5

$1,083.1$

2,289

47.3

Mot.Veh.\& Parts

838.0

876

95.7

844.0

1,357

62.2

Other Mfg.

$1,115.0$

$8,739 \quad 12.8$

$1,129.5$

2,957

38.2

${ }_{b}^{a}$ Excluding petroleum and coal products

Affiliates of nonbank parents

CEstablishment data

Nonbank affiliates, by industry of parent

Sources: Affiliate and parent data: U.S. Department of Commerce (1981), Tables I. G 4, II. G 11, II. S 1 .

Domestic industry data: 1977 Census of Manufactures,

Vol. 1, Subject Statistics, General Summary, Table 1. 
industries they are a small part of the total.

Among parents of foreign subsidiaries the motor vehicle industry had one of the higher shares of its employees abroad in 1977, almost 40 per cent, while the proportion for all manufacturing was about 30 per cent. Over a third of motor vehicle sales by U.S. companies (measured by value) were made by their overseas affiliates and a little over 30 per cent of assets were in foreign subsidiaries.

The importance of the motor vehicles and parts (or transportation equipment) industry in total U.S. manufacturing investment abroad appears to have increased somewhat over the past 50 years or so, as can be seen below:

Per Cent of Total Manufacturing

\begin{tabular}{lcc} 
Motor Vehicles & $\begin{array}{c}\text { Transport } \\
\text { and Equipment }\end{array}$ & $\begin{array}{c}\text { Traipment } \\
\text { Equipmen }\end{array}$ \\
\cline { 2 - 3 } & $\begin{array}{c}\text { Direct } \\
\text { Position }\end{array}$ & Sales \\
\cline { 2 - 3 } 1929 & 10.1 & \\
1936 & 12.1 & \\
1940 & 14.7 & \\
1950 & 12.1 & \\
1957 & 15.0 & 23.0 \\
1966 & 17.8 & 23.5 \\
1977 & 14.6 & 25.1
\end{tabular}

Source: U.S. Department of Commerce (1953), (1960), (1975), and (1981). The share in sales (not available for the early years) is much larger than the share in investment, presumably because so much of the investment is in assembly or similar operations heavily dependent on parent firms for parts and components. The gap between the two measures seems to have risen somewhat in the twenty years after 1957, possibly as a result of the 
Canadian-U.S. Auto Agreement. Taking the investment figures as less affected by duplication than the sales data, we have the impression of a rise in the importance of the industry in U.S. manufacturing investment abroad until the mid-1960's, and then some decline after that. The major increase in the role of the industry, however, was between 1929 and 1940 , when the U.S. industry's pre-eminence among the world's motor vehicle producers was least challenged.

The differences among industry groups with respect to affiliates' dependence on parent exports are shown in the following ratios:

\author{
U.S. Exports to Affiliates as \% \\ of Affiliate Sales, 1977

$\begin{array}{cc}\text { of Affiliate } & \text { Sales, } 1977 \\ \text { Total } & \text { Excluding } \\ \text { Canada }\end{array}$ \\ Al1 Manufacturing \\ 11.4 \\ 6.7 \\ Foods \\ Chemicals \\ Metals \\ 4.9 \\ 4.2 \\ 8.0 \\ 6.9 \\ 5.6 \\ 4.6 \\ 10.3 \\ 11.7 \\ 8.7 \\ Elect. and electronic equipment \\ 21.0 \\ 10.9 \\ Transportation equipment \\ 21.8 \\ 5.0 \\ Motor vehicles $\&$ equipment \\ other manufacturing \\ 9.5 \\ NA \\ 6.9 \\ Source: U.S. Department of Commerce (1981), \\ Tables II.I 4 and II.F 6. \\ Motor vehicle industry affiliates were far more dependent on imports \\ from parents than were manufacturing affiliates in general. However, that \\ high level of dependence on parents reflected largely the activities of \\ Canadian affiliates; the ratios for those in other countries were similar \\ to those for the industries least dependent on U.S. materials and com- \\ ponents. Aside from affiliates in Canada, it was those in the machinery
}


and electrical equipment industries that were most dependent on components and supplies imported from the United States.

A good deal of information about the industry group, transportation equipment, is available from the published data on the 1977 investment survey. The principal defect in these data as background for our later analysis, which is confined to auto and auto parts companies and affiliates, is that they include the aircraft industry. However, some information was published about the motor vehicle and equipment industry itself. Fortunately for our purpose, the motor vehicle industry accounted for the great majority of affiliate sales of transportation equipment and of other variables we use, as can be seen in Table 2 .

Transportation equipment affiliates in sub-industries other than motor vehicles and equipment clearly played a negligible role in the activity of U.S. majority-owned affiliates and in U.S. firms' exports to such affiliates. Most of their sales were by affiliates that were not majority-owned, almost entirely in Europe, and we can therefore eliminate most of their activity from our analysis by confining ourselves to majority-owned affiliates. We must do that in any case for many purposes because the non-majority-owned affiliates did not report many of the variables we are interested in.

The non-motor-vehicle part of the industry was important in U.S. parent exports. It accounted for well over two-thirds of exports to unaffiliated foreigners, and almost 90 per cent of its exports, particularly aircraft, were sold to unaffiliated buyers.

Among motor vehicle and equipment affiliates, the great bulk of sales were by those in developed countries. Affiliates in Europe, the ones we con- 
Table 2

Division of Transportation Equipment Industry between Motor Vehicles and Other, for Various Characteristics, 1977 (Unit: millions of dollars)

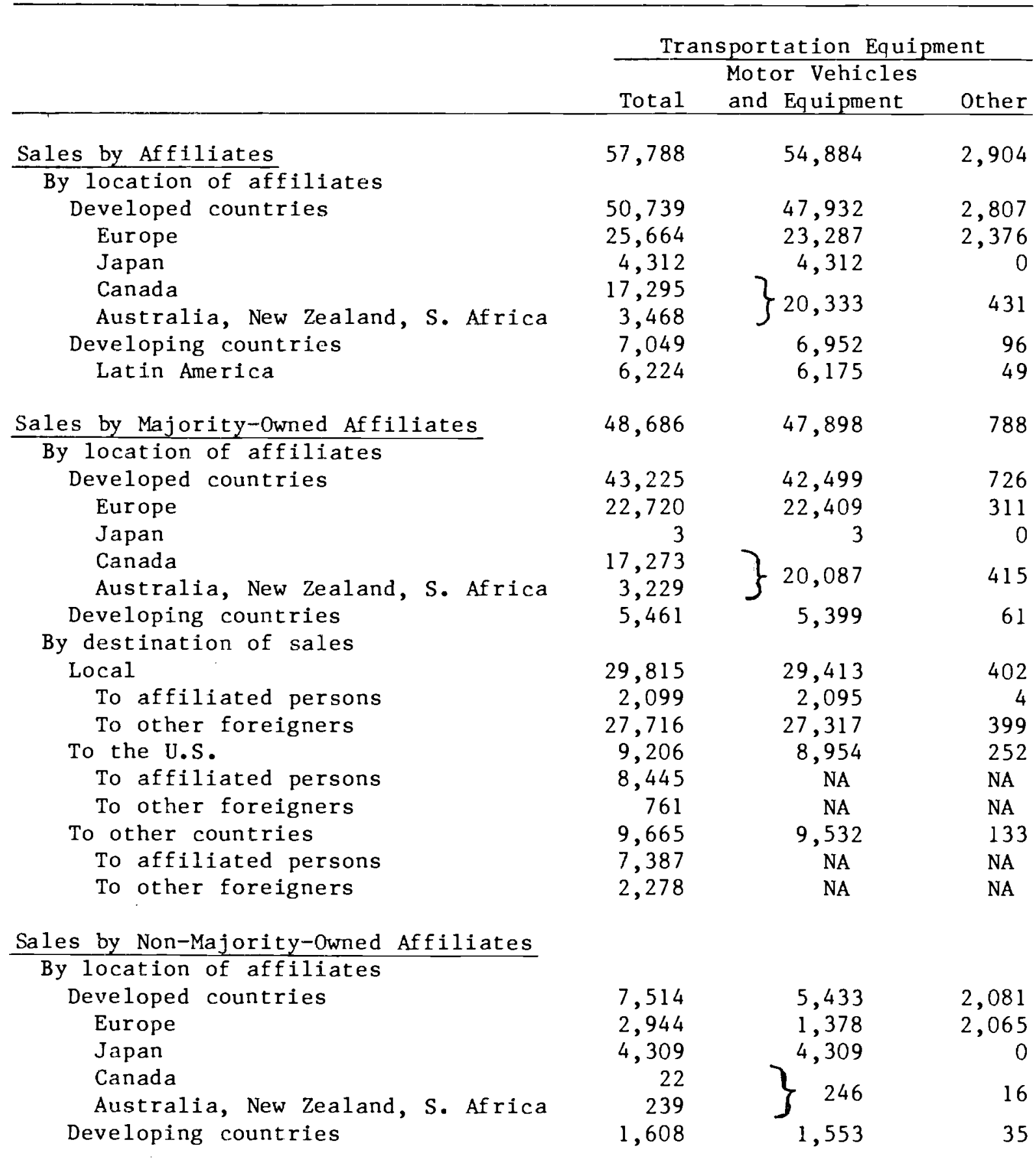


Table 2 (concluded)

\begin{tabular}{|c|c|c|c|}
\hline & \multicolumn{3}{|c|}{ Transportation Equipment } \\
\hline & Total & $\begin{array}{l}\text { Motor Vehicles } \\
\text { and Equipment }\end{array}$ & Other \\
\hline \multicolumn{4}{|l|}{ U.S. Exports to Majority-Owned } \\
\hline$\frac{\text { Affiliates }}{\text { By product }}$ & 12,651 & 11,903 & 747 \\
\hline Machinery & 966 & 959 & 7 \\
\hline $\begin{array}{l}\text { Road motor vehicles and parts } \\
\text { By location of affiliates }\end{array}$ & 10,530 & 10,529 & 1 \\
\hline Developed countries & 10,771 & 10,622 & 149 \\
\hline Canada & 10,100 & 9,987 & 114 \\
\hline Europe & 445 & NA & NA \\
\hline Japan & 1 & 1 & 0 \\
\hline Australia, New Zealand, S. Africa & 225 & NA & NA \\
\hline Developing countries & 1,035 & 1,028 & 7 \\
\hline Latin America & 1,020 & NA & NA \\
\hline \multicolumn{4}{|l|}{ By type of use } \\
\hline Capital equipment & 98 & 96 & 2 \\
\hline For resale without further processing & 7,593 & 7,543 & 50 \\
\hline Other & 4,115 & 4,011 & 104 \\
\hline \multicolumn{4}{|l|}{ By type of U.S. exporter } \\
\hline $\begin{array}{l}\text { Parents } \\
\text { Others }\end{array}$ & $\begin{array}{r}10,175 \\
2,476\end{array}$ & $\begin{array}{l}9,638 \\
2,265\end{array}$ & $\begin{array}{l}536 \\
214\end{array}$ \\
\hline \multicolumn{4}{|l|}{ U.S. Parent Exports to Unaffiliated } \\
\hline Foreigners & 10,474 & 3,313 & 7,161 \\
\hline Machinery & 2,149 & 740 & 1,409 \\
\hline Road motor vehicles and parts & 1,964 & 1,795 & 169 \\
\hline Other transportation equipment & 5,735 & 648 & 5,105 \\
\hline
\end{tabular}

Source: U.S. Department of Commerce (1981), Tables II.F6, II.T3, III.F6, III.H2, III.I2, III.I4, III I.13, III.T1 
centrate on, accounted for about half, and those in Canada for most of the rest. Minority-owned affiliates were dominant only in Japan, where they were almost the only ones. They were also relatively important in developing countries: over a fifth of affiliate sales in these countries as compared to 6 per cent in Europe and 11 per cent in developed countries as a whole. Within the developing countries, affiliates in Latin American accounted for almost 90 per cent of U.S. affiliate sales.

Over a third of sales by majority-owned transport equipment affiliates were to affiliated companies, including the parents. The bulk of these intracompany sales were exports and most exports (over three quarters) were intracompany sales. However, there were $\$ 2$ billion in intracompany sales within the same host countries, probably from parts affiliates to vehicle production affiliates, and from the latter to distributors. 90 per cent of sales to nonaffiliated entities were local, but there were almost $\$ 3$ billion across country boundaries.

European affiliates exported more than 40 per cent of their production, while affiliates in developing countries produced almost entirely for sale in their host-countries. In other words, the developing-country affiliates were operating in relatively sma11, isolated markets, while those in Europe operated in a world-wide or at least continental market. The small amount of exports from developing-country affiliates was split about evenly between the United States and other countries, but less than 6 per cent of European exports came to the United States.

Another distinction between manufacturing affiliates in Europe and those in developing countries is that the former were almost completely 
independent of their parents, and of the U.S. in general, for parts and components. Imports from the U.S. by majority-owned affiliates in Europe were less than 3 per cent of their sales, as compared with almost 20 per cent for those in developing countries.

U.S. affiliates all around the world increased their export orientation in the decade before 1977, as can be seen in Table 3. The affiliates in developed countries, aside from those in Canada, were exporting to countries other than the United States. Those in Europe had already exported about a third of their production in 1966, and that share rose to over 40 per cent in 1977. Affiliates in developing countries had exported virtually nothing in 1966 but by 1977 were exporting over 7 per cent of their production, about half of which went to the United States. In two of the locations with relatively large U.S. affiliate production, Brazil and Mexico, the export ratios were higher, and Mexico exported mainly to the U.S. Affiliates in Venezuela, however, did virtually no exporting, although their sales, in the aggregate, were larger than those of Mexico. Since the Venezuelan market appeared to offer as much opportunity for achieving scale economies as the Mexican market, one might guess that the difference between the two countries owed something to government intervention. 
Table 3

Exports and Total Sales by U.S. Majority-Owned Transportation Equipment Affiliates, 1966 and 1977

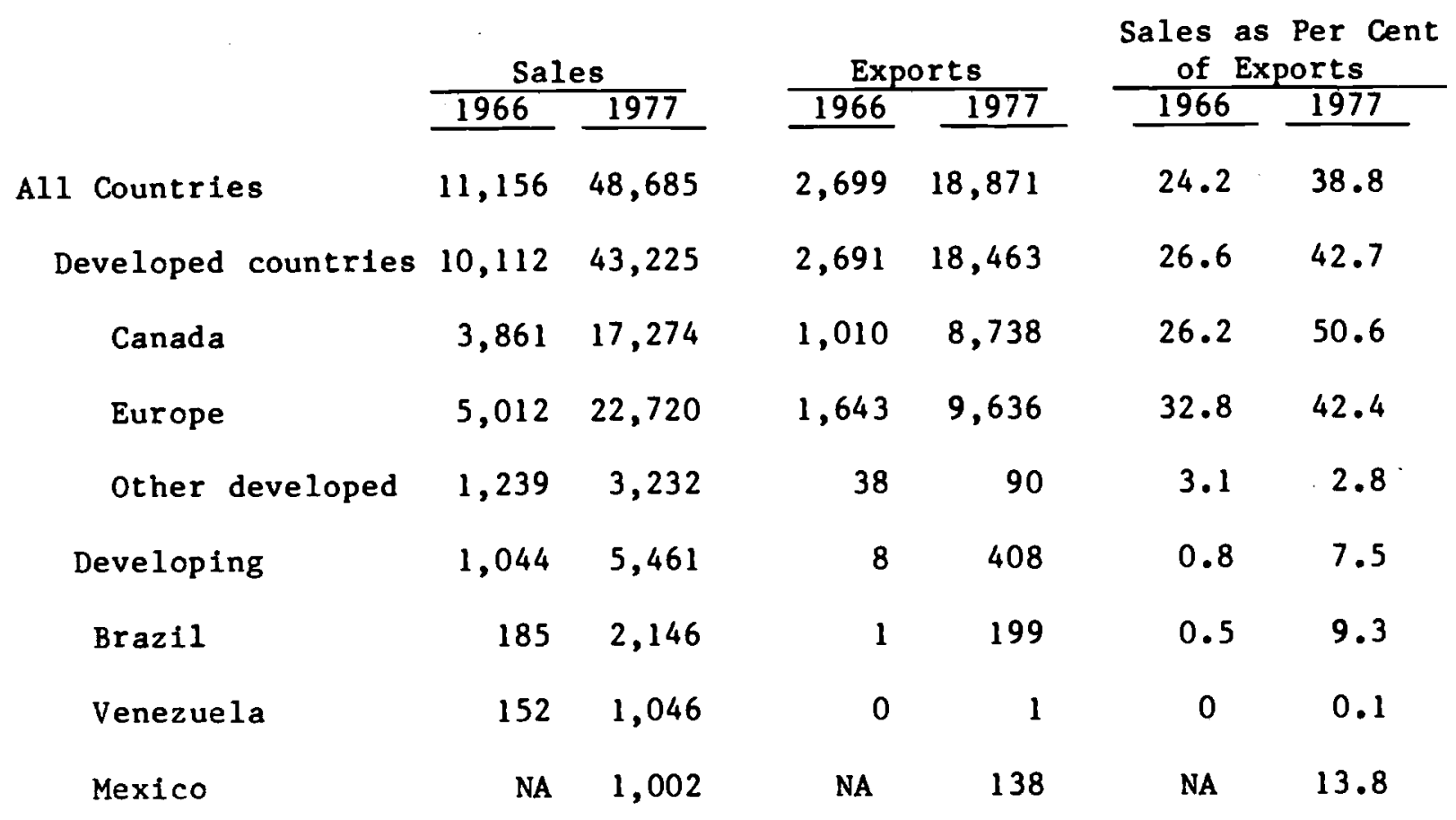

Source: Lipsey and Kravis (1982), Table A-7. 


\section{THE LOCATION OF OVERSEAS MANUFACTURING}

\section{a. General Factors in the Location of Multinational Firm Activities}

While many of the earlier discussions of the behavior of multinational

firms were based mainly on theories of international trade and capital movements, it has become clear that such considerations alone explain only a small part of the phenomenon. Following the work of Buckley and Casson (1976), Caves (1971), (1974), (1982), Dunning (1971), (1974), Horst (1974), Magee (1977), and others, it is increasingly recognized that the explanation of the behavior of multinational firms requires a mixture of the considerations that are part of international trade and finance with those that are usually thought of as industrial organization issues.

The application of trade theory to the exporting decisions of multinationals has usually started with the assumption that a purely competitive world leaves no room for such firms and that a minimum departure from such a world is that individual firms must be assumed to possess some firmspecific advantages that give them the ability to sell in foreign markets in competition with local firms. These advantages give the firm some niche in each market--some demand, not infinitely elastic, for its products. The trade and investment problem is then the allocation between production and exporting, or in more elaborate analyses, among production, exporting, and licensing, as ways of serving this demand and maximizing profits. In this framework, the decision to invest and the decision to export from the home country are a single decision. The relation between production in a market and home-country exports to that market is necessarily negative, if properly measured. 
The auto industry, at least in the early days, presented an unusually clear case in which the direct investment involved a flow of technology rather than of capital. The Ford subsidiaries in both Canada in 1903 and in the U.K. in 1911 were established with no monetary capital investment by the parent company but with their contribution of the company name, "... patents, highly-valuable designs, 'know-how,' and technical assistance." (Maxcy, 1981, pp. 64-66, and Wilkins and Hil1, 1964, p. 18).

The limitations of this model were pointed out by Horst (1974) among others and demonstrated by the fact that the expected negative relationship has proved extremely elusive in empirical studies. For one thing, major investment decisions are long-term ones, while decisions about how to supply a market are probably made more frequently, with the location of producing facilities taken as given for short and even intermediate periods. More important, perhaps, is that the main reason for establishing a foreign plant is often not to minimize cost but to shift the demand curve in the firm's favor. There are many ways in which this can happen. Many buyers, especially governmental, may have a preference or even an absolute requirement for locally produced items. A local plant provides assurance to the buyer of a complex product that the seller has a long-term interest in and commitment to the market and is likely to provide continued service facilities. A local plant may make it easier for a producer to tailor its product or part of its product line to local needs and preferences. Local production of some items may be required by the government as the price for permission to import the rest of the line. The reputation of locally produced items may increase the demand for the rest of the firm's products. 
An aspect of several of these factors affecting the demand for a firm's products is that they involve multiproduct rather than single-product firms. That does not necessarily mean that they straddle many SIC or SITC groups. At the minimum, the multiple products may be only slightly differentiated versions of what is essentially the same product. However, "... in actual practice, virtually all multinational firms are also multiproduct firms" (Horst 1974). b. The Segmentation of Motor Vehicle Markets

The location of the motor vehicle industry and various elements of its operations around the world have been determined, to a larger degree than in most industries, by governmental actions and regulations. Among the earliest of these were high tariffs on imported vehicles and the high tax rates on fuel in European countries. Both of these tended to segment markets so as to limit the importance of imports as a source of supply. In the case of fuel taxes, the effect was to segment markets not only geographically but also by the characteristics of cars, with the European (and later, Japanese) markets geared to smaller cars than the U.S. market. In recent years, the forms of government intervention have multiplied, the current ones being mainly the many types of local content requirements, monopoly rights, subsidies, and other devices prevalent in almost all developing countries, some of which have now been proposed also for the United States. The history of the trade and investment by U.S. motor vehicle companies is therefore a tale of continuous adaptation not only to changes in economic circumstances, labor cost, capital cost, transport cost, market location, and other changing elements of comparative advantage, but also to 
changes in the extent and types of government intervention.

Almost from the earliest years of the motor vehicle industry, governments seem to have been determined to reserve as large as possible a share of their markets for production within those markets. A Canadian tariff of 35 per cent on complete cars, but lower on parts, was one of the inducements for Ford's initial Canadian operation (Wilkins and Hil1, 1963, p. 15). The British duties of $1 / 3$ on car imports imposed during world War $I$ led to a declaration by Ford that "... in the near future Ford cars sold in the UK will be entirely of local manufacture...". (ibid, p. 102). The Australian assembly industry developed behind a war-time prohibition on imports of complete cars to conserve shipping space (ibid, p. 124). An'increase in the German tariff on autos and parts, passed in 1927 "... sounded the death-knell for American assembly plants there." (ibid, p. 160).

Tariffs encouraged local market production but did not determine that it should be of products different from those in the home market. Measures to base excise taxes on horsepower and to tax fuel heavily performed that function. The English Finance Act, effective in 1921, imposed a tax based on the number of cylinders and their diameter, which raised the price of the Ford Model $T$ well above that of competing British cars (ibid, p. 142) and through the 1920's"... the small car competitors relentlessly harried the Ford." (ibid, p. 145).

The segmentation of markets for automobiles was described many years ago. In a list of reasons for separate organizations in Europe, Southard 
(1931)

observed that:

\begin{abstract}
"Certain of these market differences are imposed by abnormal fiscal conditions. For example, the annual tax on a 20 horsepower automobile in 1928 was, in England, \$153, in France $\$ 32.50$, and in Germany $\$ 200$. Taxes of this magnitude on cars of moderate horsepower, coupled with higher priced gasoline, has developed an artificial motorcar market in Europe which places the mean far below 20 horsepower. With the bulk of the European market thus demanding a low-powered car, the American motor-car producer is faced with a difficult marketing situation which, barring a resumption of a more normal taxation and a higher level of purchasing power, can only be met by the production of a car which, in the main, is unsuitable for the American market.*"

"*It is this abnormal tax situation, in the final analysis, which, rather than tariffs, has given effective protection to the European motor-car producer."
\end{abstract}

The segmentation of markets that resulted from these government actions as well as from other characteristics of the United States and European markets can be observed in data for the mid-1960's, before the rises in the price of oil and government responses to it greatly altered the pattern of consumer demand. One indication is given by the distribution of weights of cars produced in the United States and in four European countries, the U.K., Germany, France, and Italy. 
Number of Domestically Produced Car Models, by Weight, 1964

\begin{tabular}{lrrrrr} 
& \multicolumn{2}{c}{ U.S. } & & \multicolumn{2}{c}{ Europe } \\
\cline { 2 - 3 } Weight (1bs:) & No. & $\%$ & & No. & $\%$ \\
Under 1,200 & 0 & 0 & & 4 & 2.8 \\
1,200-1,599 & 0 & 0 & & 19 & 13.5 \\
$1,600-1,999$ & 0 & 0 & & 47 & 33.3 \\
$2,000-2,399$ & 3 & 1.5 & & 29 & 20.6 \\
$2,400-2,799$ & 49 & 25.1 & & 20 & 14.2 \\
$2,800-3,199$ & 60 & 30.8 & & 11 & 7.8 \\
$3,200-3,599$ & 52 & 26.7 & & 9 & 6.4 \\
3,600 \& over & 31 & 15.9 & & 2 & 1.4 \\
\multicolumn{1}{c}{ Tota1 } & 195 & 100.0 & & 141 & 100.0
\end{tabular}

Source: Kravis and Lipsey (1971), p. 513. Some models with very small production were not included in the sample.

Over 70 per cent of European production was in a range of sizes below all except $11 / 2$ per cent of U.S. production. Almost three quarters of U.S. production was in size ranges that included only 15 per cent of European production. The lack of overlap between the car sizes of the different markets was even more extreme for the United States compared with continenta1 Europe.

A similar comparison can be made for horsepower. Almost two thirds of the European models were below the level of the lowest horsepower U.S. car, and four fifths were below the level of all but 5 per cent of U.S. models. Almost two-thirds of U.S. cars had higher horsepower than all but about 3 per cent of European cars. 
Number of Domestically Produced Car Models, by Horsepower, 1964

Horsepower

Under 50

50-74

75-99

100-149

$150-199$

200-249

250-299

$300 \&$ over

Total

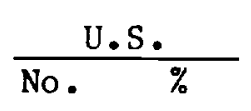

0

$0 \quad 0$

94.6

$61 \quad 31.3$

$52 \quad 26.7$

$24 \quad 12.3$

$23 \quad 11.8$

$26 \quad 13.3$

195100.0 $\frac{\text { Europe }}{\text { No. } \%}$

\begin{tabular}{rr}
26 & 18.4 \\
65 & 46.1 \\
24 & 17.0 \\
22 & 15.6 \\
1 & .7 \\
2 & 1.4 \\
1 & .7 \\
0 & 0 \\
\hline
\end{tabular}

$141 \quad 100.0$

Source: Kravis and Lipsey (1971), p. 512. Some models with very small production were not included in the sample.

Another indication of the segmentation of markets is that differences in the level of taxes and in the ability to take advantage of scale economies for cars of different types led to extreme disparities in "estimated"1domestic prices between cars of typical U.S. specifications and cars of foreign specifications. Estimated prices for an "average" U.S. car were three times as high in Europe as in the United States, while estimated prices for an "average" foreign car were only 10 per cent higher than in the United States. Estimated U.S. prices for the smallest of five types were more than a third higher than European prices, while estimated European prices for a large, standard U.S. car were two and a half times the U.S. price (Kravis and Lipsey, 1971, pp. 590 and 517). While these prices are highly conjectural as estimates of what cars not being produced

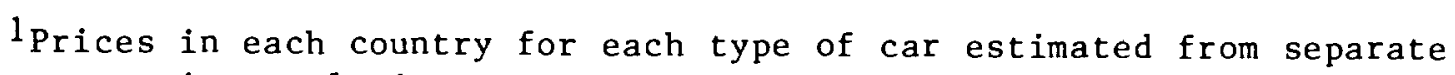
country equations relating car prices to car characteristics. 
In a market would have cost if they had been produced there, they do represent actual price gradients for the characteristics of the cars that were being produced. In this sense they do indicate the degree to which these two markets were isolated from each other. A similar analysis conducted for 1969 found European prices for the U.S. mix of cars 20 to 84 per cent above U.S. prices and for each country's own $\mathrm{mix}, 15$ per cent below to 4 per cent above U.S. prices. The corresponding estimates for Japan were 11 per cent above the U.S. for the U.S. car types and 11 per cent below the U.S. for Japanese car types (Kravis, Kenessey, Heston, and Summers, 1975, pp. 115-116). Recent events -- in particular the difficulty U.S. producers have had in manufacturing small cars economically in the U.S. -- suggest that very different technologies and production functions evolved in the U.S. and other countries as a result of this market segmentation.

While the segmentation of the world market into European production on one hand and U.S. and Canadian production on the other shaped the relationship of U.S. companies to the European market, the segmentation introduced by developing countries after World War II was of a somewhat different type. The interventions were more elaborate and specific and varied widely among the countries according to the sizes of their markets and the degree to which they thought foreign producers could be induced to shift production. The industries built up were more inward-looking than those that had grown up in Europe, each country developing production almost entirely for its own market. The tendency was to fragment the industry, even at the cost of diseconomies of small-scale production. It has only been after a considerable period of such policies that some of the developing countries have begun to add export incentives or 
requirements to local content regulation and to move towards accepting integration into worldwide production networks as a substitute for selfcontained motor vehicle industries as ultimate objectives.

In a world of segmented markets in which there were no differences in income levels, tastes, factor or materials prices, no economies of scale, and no costs to a firm of transferring its technology from country to country, we would expect to find multinationals' production geared to the location of markets. Differences in income levels would lead to a prediction of higher levels of production in higher-income countries, if demand for autos is income elastic. Allowing for economies of scale would lead us to predict still further concentration of production in large markets, since costs and prices would be lower there. Allowing for some amount of trade among countries, even with high transport costs or other barriers, would also add to the tendency towards concentration and the disappearance of production in the smallest markets, since the economies of scale might outweigh the transfer costs. High costs of transferring technology to some locations because of wide differences in language or customs would discourage production there. High labor costs would presumably discourage the location of production.

The effect of local content requirements or similar cost-increasing measures is not so easy to anticipate and may be particularly hard to measure because the existence of the requirements may itself be a function of the other variables, such as market size, that we use to explain the entry and level of activity of U.S. firms. Local content regulations were seen by developing countries as a way of encouraging foreign invest- 
ment in the hope of stimulating industrial growth. They may have been considered to be more effective than tariffs as a way of promoting entry since there were no indigenous auto companies in these countries to take advantage of tariff protection. A government can guarantee that its market will be closed to a firm that does not comply with the regulation. It also is able to limit the number of entrants into the market and thereby give an entrant the chance to reach a scale of production that is not too uneconomical, something tariffs alone could not do. Often one sees local content regulations combined with different forms of investment incentives including tax and tariff concessions and subsidies which effectively lower the cost functions for the entering firms and may allow them to return a profit even if the costs of producing in an LDC tend to be higher than elsewhere because of the lack of infrastructure, the inability to realize economies of scale, and the requirements for local content.

The enactment of local content regulation may be directed at purposes other than forcing entry. Another possibility is that it is a way of extracting some rents from the foreign investors for the host-country government, especially when these rents have been created by other hostgovernment policies. In this case also, the size of the rents to be extracted may be related to the market size and other variables determining location.

In a small market, local content requirements may reduce the probability of location. Production on a small scale without imported components may be so inefficient and expensive that a company would rather lose that market than comply with the regulations, and the effect on probability of 
entry would then be negative over that range of market sizes (see Baranson, 1969, and Picard, 1970, for estimates of the effects on costs of small scale and high degrees of local integration).

In some of our analyses we use investment incentives as a variable in addition to local content requirements. While local content requirements are cost-increasing, investment incentives should be cost-reducing and should, therefore, be a positive influence on both the probability of investing and the size of operations. Unlike local content rules, investment incentives may have stronger effects in non-segmented markets, since they may increase the profitability of production for sale in many markets.

We have not used the investment incentive variable as frequently as the local content rules in our analyses. One reason is that our information on incentives, confined to answers to the 1977 Department of Commerce investment survey, lacked data for countries with no U.S. investors. For this reason it could not be used in analyses across all countries. Another problem is that the presence of U.S. affiliates was strongly correlated with that of local content requirements. In Europe, few affiliates reported local content rules without also reporting incentives. The local content variable, therefore, represents a combination of the two. In developing countries, there were local content rules without incentives but hardly any incentives without local content requirements. The incentives variable in that case, therefore, represented the combination of the two regulations, while the local content variable represented the effect of local content rules without incentives.

We have here the possibility of two measurement problems. One is that 
a government may give up or avoid local content legislation if such regulations would cause firms to abandon or not enter the country's market. We would then not be able to observe the negative relationship between local content legislation and entry, and our results would be biased toward a positive relationship. The other problem, related to the first, is that of simultaneity bias; while local content regulations may increase the probability that a foreign company will locate production in a host country, the likelihood that a government will decide to enact and retain such legislation and the stringency of its provisions may not be exogenous.

A country may not have local content legislation but would impose it If any company proposed to enter or began production there. Second, larger levels of affiliate production may imply a greater commitment to a market and therefore tempt the host government to impose conditions on the firm's continued activity there.

Examining the timing of legislation and entry may give us some hints as to the importance of the simultaneity issue. If it were found that entry tended to follow legislation with a relatively short lag while legislation did not tend to follow entry we would be more willing to ignore the simultaneity issue in our statistical analysis.

We do not include tariffs at this point and believe that tariffs have not played as important a role in encouraging investment in LDC's as they did earlier in the developed countries. Of the countries which have imposed local content regulation for automobile companies, over $3 / 4$ 's are developing countries. 


\section{c. The Decision to Locate or Probability of Entry}

In this investigation we have treated the automobile companies separately from the parts producers. The auto companies sell mainly consumer goods for which product differentiation, brand names, and reputation among buyers are probably important. The parts producers, on the other hand, sell mainly to auto and truck manufacturers, both U.S. and foreign. They may be constrained more by cost considerations and may be able to depend for their firm-specific comparative advantage on their worldwide reputations rather than on the knowledge of each country's buyers. They may also, to some extent, be captives of the auto companies, locating in a particular country because the auto companies are there. In some cases, the auto producers were reported to have persuaded the parts producers to follow them. ${ }^{2}$

For the auto companies we expect the probability of entry to be affected by the size of the market, as measured by the population or income of the country. If markets were largely isolated by distance or governmental restrictions we could think of this as a demand factor. Alternatively,

2 Referring to Brazil in the late $1950^{\prime} \mathrm{s}$, Gordon and Grommers (1962, p. 58) wrote "A major factor in the decisions of almost all participating parts manufacturers was persuasion by the vehicle makers. One company ... was initially not inclined to move into Brazil. When a number of vehicle manufacturers, which are the company's main customers in the United States, suggested that it provide technical assistance to a local Brazilian firm, it had little choice but to follow this suggestion. Another company was much influenced by the fact that its main U.S. customer ... wanted a U.S. supplier of the part concerned in Brazil and that if this supplier would not come, the customer would have to ask someone else ... the maker did not want to run the risk that a smaller competitor might edge into its domestic market by supplying its U.S. customers satisfactorily in Brazil." Following the same pattern, Japanese parts producers are reported to be joining Japanese auto producers in the U.S. See, for example, "Suppliers join Honda in Ohio," N.Y. Times, July 6, 1984, and "Nippondenso to Build Car Parts Plant in U.S.," Wall Street Journal, August 10, 1984. 
we can think of market size as a cost factor: location within a large market is a way of minimizing the cost of supplying that market, eliminating transport or other costs of supplying products across national boundaries. Another cost factor in a particular market is the cost of labor or other factors of production. The existence and nature of government regulations is also a cost factor, determining not only the cost of supplying the market from outside but also costs of operating inside the market. We assume that capital costs are a parent-firm characteristic rather than a countryof-location characteristic; that is, for any one firm they do not differ among countries.

The demand for parts company products is partly a derived demand. It would be desirable to include among the parts company decision variables, the activity of auto companies in that country where that is possible. The point at which manufacturing in a country becomes profitable for a parts company would be affected by whether and at what level auto companies locate their manufacturing and assembly affiliates there. A fact that suggests such dependence is that there are hardly any parts company plants in countries without U.S. auto company plants. Parts companies' location choices would also be would also be affected by labor and other costs and by government regulation of not only their operations but also those of their main customers, the auto companies. They would be influenced by market size, aside from its effect on auto company location, through its effect on the market for replacement parts.

The decision to locate implies a yes-no response from the firm and therefore necessitates the use of a statistical technique appropriate for a binary dependent variable. We posit that a profit maximizing firm has an 
estimate of the potential return from investment in each country. This potential could be measured by a continuous index, $I^{*}$, which is unobservable. We are, however, able to observe its sign. When $I^{*}$ is greater than 0 we observe investment in a country and we define $I=1$. Otherwise, $I=0.3$ We postulate that auto company $j$ 's tendency to invest in country $i$ is defined by

(1) $I_{i j}^{*}=\alpha_{1} W_{i}+\alpha_{2} M_{i}+\alpha_{3} L_{i}+\alpha_{4} R_{i} R E l_{i}+\varepsilon_{i}$

$$
\text { where } \begin{aligned}
I_{i j}= & 1 \text { when } I_{i j}^{\star}>0 \\
= & 0 \text { otherwise } \\
W_{i}= & \text { average relative wage in country } i \text {, adjusted } \\
& \text { or the quality of labor. } \\
L^{\prime}= & 1 \text { if country } i \text { is an LDC; } \\
& 0 \text { otherwise } \\
M_{i}= & \text { the size of the market in country } i . \\
R E G_{i}= & 1 \text { if local content regulations exist in country } i \\
= & 0 \text { otherwise }
\end{aligned}
$$

The logit model estimated for the probability of entry by auto companies is:

(2) $\quad \log \frac{P_{i}}{1-P_{i}}=\alpha_{1} w_{i}+\alpha_{2} M_{i}+\alpha_{3} L_{i}+\alpha_{4} R R_{i} l_{i}+\varepsilon_{i}$

We expect, that

(1) $\alpha_{1}<0$. We do not have an adequate measure of the price of labor of

${ }^{3}$ We could also define $I=$ some continuous function, ax $+e$, when $I^{*}$ is greater than 0 . That involves the use of a TOBIT estimation technique, as seen below. 
a particular quality in country 1. If the measure we use, real income per capita, acts as a proxy for the price of labor, we expect the probability that an automoblle company locates a manufacturing affiliate there to be negatively related to 1t. If, however, it acts as a proxy for the level of development of country $i$ or the level of discretionary income of consumers in country 1 , we expect a positive coefficient.

(2) $\alpha_{2}>0$. The larger the market the greater the saving in transport cost, market information, tariffs, etc. from locating production there.

(3) $\alpha_{3}<0$. We assume that, given the size of the market and the price of labor, the cost of building and installing plant and equipment may be higher in LDC's because support services are scarce, replacement parts may be difficult to obtain and labor training costs may be high. The overall risk may be higher, including the risk of expropriation of either assets or profits.

(4) $\alpha_{4}>0$. We cannot predict the effect of local content regulations, for reasons described earlier. In a sufficiently attractive market the effect should be to increase the probability of location.

Parts company j's tendency to invest in country $i$ would be defined by

$$
\text { (3) } I_{i j}^{*}=\alpha_{1} \mathrm{~W}_{1}+\alpha_{2} \mathrm{M}_{1}+\alpha_{3} \mathrm{LDC}_{i}+\alpha 4 \mathrm{AUTO}_{i}+\alpha \mathrm{REG}_{1}+\varepsilon_{i}
$$

where

$$
\begin{aligned}
I_{j} & =1 \text { when } I_{i j}^{*}>0 \\
& =0 \text { otherwise }
\end{aligned}
$$

$$
\begin{aligned}
\operatorname{AUTO}_{i}= & 1 \text { if at least one manufacturing affiliate of a U.S. } \\
& \text { automobile company is located in country } i \\
= & 0 \text { otherwise }
\end{aligned}
$$




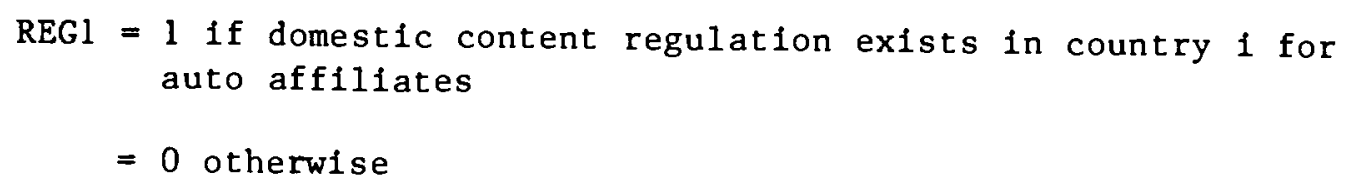

For parts companies we would expect:

(1) $\alpha_{1}<0$.

(2) $\alpha_{2}>0$.

(3) $a_{3}<0$. The reasons for our expectations regarding $\alpha_{1}, \alpha_{2}$, and $\alpha_{3}$ are essentially the same as for auto companies.

(4) $\alpha 4>0$. Parts companies "follow" auto companies abroad.

(5) $\alpha 5>0$. Local content regulation imposed on automobile companies may encourage parts companies to locate in those countries. In order to satify such requirements, auto companies may demand that those parts companies that do business with them in the U.S. follow them to countries which do not allow the automobile industry to import parts.

\section{Empirical Results}

\section{a. Logit Analysis of Location}

The logit specification is estimated using the maximum likelihood method first with data on 114 countries and then for three groups of countries separately. First we look at the location behavior of automobile company affiliates, then of parts company affiliates. Finally we touch on the simultaneity issue by treating local content regulations as dependent variables. The exact definitions of the variables we use are given in the notes to Appendix Table A-1. 
The first set of equations attempts to explain the presence of at least one U.S. automobile company affiliate, whether it is a manufacturing or nonmanufacturing affiliate. Local content regulations encouraged entry into a host country. The dummy variable for a developing country was, as expected, a consistently negative influence and per capita income a positive influence on probability of entry. Although each of these two variables had a smaller coefficient when the other was introduced into the equation, it remained significant. In other world, status as a developed country in our classification does seem to have some meaning beyond per capita income, and while per capita income does not seem to perform as a measure of the price of labor, it does have some influence other than as another way of defining status as a developed country. Another indication of this influence is that in equations for developing countries alone, per capita income remains a positive influence on U.S. affiliate presence. Coefficients for the regulation variable are larger in equations for developing countries, suggesting its stronger effect on entry there. If we confine the analysis to the presence of manufacturing operations, only the local content regulation variable is a consistent influence, always positive. The LDC and per capita income coefficients do remain negative and positive respectively, but are not always significant.

In addition to the probability that at least one U.S. auto firm would locate a manufacturing affiliate in a particular country, we can also calculate the probability that a particular firm would locate an affiliate in a country. In the first set of equations already described (A-1 to $A-13$ ), if at least one firm located an affiliate in a country, it was recorded as what 
could be called 100 percent location. In the following equations there are four observations for each country: the decisions of each of the four auto companies to locate or not to locate in that country. If one of the four auto companies had at least one manufacturing affiliate in a country, that would be recorded as $\mathrm{L}=1$ for that firm in that country. If a company did not locate an affiliate in that country, we would designate $L=0$ for that firm in that country.

This disaggregation by company largely confirmed the results in the equations for any U.S. presence. For all affiliates, including nonmanufacturing, higher per capita income encouraged entry, classification of a country as developing was a negative influence, both were significant when they were included in the same equations, and per capita income was significant within the group of developing countries.

The distinction between results for Europe and those for developing countries comes out clearly in the equations for entry by manufacturing affiliates. Per capita income was a significant positive influence on entry in developing countries but not in Europe, while market size, as measured by aggregate national product, was significant in Europe, but not consistently in developing countries. A possible interpretation of this difference would be that the size of the market for autos, for which GDP is only a rough proxy, depends on both total and per capita income in developing countries, among which per capita incomes vary greatly, but is well represented by aggregate GDP in developed countries, among which per capita income levels do not differ so much. Local content regulation appears to have been a stronger encouragement to entry in developing countries than in Europe. 
As we mentioned earlier, it is likely that the existence of local content requirements in a country is not completely independent of the country characteristics that would induce entry even without the regulations. We have made a test of that possibility by trying to predict the existence of these regulations, as with equations (4) and (5):

(4) $\mathrm{REGl}_{1}$ (AUTO) $=1.5 * * \mathrm{LDC}_{i}+1.0 * * \operatorname{lngDP7}_{i}$

(5) $\operatorname{REGl}_{1}\left(\right.$ AUTO) $=.97 \operatorname{lngDP7}_{1}-1.9 * \operatorname{RGDPC}_{1} 7_{i}$

** = significant at $1 \%$ level

When GDP is included with GDP per capita or the LDC variable they are all consistently significant at the 1 percent level. As expected, the fact that a country was an LDC increased the probability that it would impose local content regulations on an automobile affiliate. Alternatively, we can say that a higher level of per capita income decreased that probability.

Given that a country was an LDC, the larger the size of its local market, the greater the probability that it would have local content legislation. A country with a very small local market might find that content regulations simply discouraged any entry at all by destroying the profitability of local production or assembly. It may be that the smaller LDC's needed to include a package of local content legislation and subsidies to convince firms to enter. 
The equations for the entry of any U.S. parts company (Table A-2) show that the most consistent, and always positive, influence was the existence of a U.S. auto company manufacturing operation in the market. Market size was a positive influence on entry, even when auto affiliate presence was included in the equation. Income per capita was positively related to entry and classification as an LDC negatively related, and the two variables (really two versions of the same variable) were little affected by the inclusion of the auto manufacturing variable. The story was different for the indicator of local content regulation. That variable virtually disappeared when auto manufacturing presence was included, an indication that such regulation attracted parts companies by attracting auto manufacturing operations rather than through their effect on the purchasing behavior of already existing U.S. auto companies.

Another indication of the relation between motor vehicle affiliates and parts affiliates is given by Table 4, which shows the dates of first manufacturing in three countries by motor vehicle and parts affiliates of U.S. companies. We have picked the dates to emphasize the clustering of initial manufacturing dates but the timing does suggest that either the parts affiliates followed the path of the motor vehicle producers or that they both responded at certain times to changes in host government regulations. The latter explanation is reinforced by the Brazilian case. Two of the motor vehicle affiliates and nine of the parts affiliates were established in 1957-60, soon after enactment of a program for the establishment of an automobile industry. This program, which called for increases in the "national composition" of vehicles (measured by weight) to over 90 per cent between 1956 and 1960, followed an earlier one which denied import licenses 
TABLE 4

Dates of First Manufacturing by U.S.-Owned Motor Vehicle and Parts Company Affillates in Argentina, Brazil, and Mexico

\begin{tabular}{|c|c|c|c|c|c|c|c|}
\hline & $\begin{array}{c}\text { Total } \\
\text { Number of } \\
\text { Manufac- } \\
\text { turing } \\
\text { Affiliates }\end{array}$ & & & tes of $\mathrm{Fi}$ & rst Manuf & acturing & \\
\hline Argentina & & Before & 1959 & $1959-61$ & $1962-65$ & $1966-67$ & $1968-71$ \\
\hline $\begin{array}{l}\text { Motor Vehicles } \\
\text { Parts }\end{array}$ & $\begin{array}{r}5 \\
12\end{array}$ & & $\begin{array}{l}0 \\
1\end{array}$ & $\begin{array}{l}3 \\
5\end{array}$ & $\begin{array}{l}0 \\
1\end{array}$ & $\begin{array}{l}2 \\
5\end{array}$ & $\begin{array}{l}0 \\
0\end{array}$ \\
\hline Brazil & & Before & 1957 & $1957-60$ & $1961-66$ & 1967 & $1968-71$ \\
\hline $\begin{array}{l}\text { Motor Vehicles } \\
\text { Parts }\end{array}$ & $\begin{array}{r}3 \\
16\end{array}$ & & $\begin{array}{l}0 \\
4\end{array}$ & $\begin{array}{l}2 \\
9\end{array}$ & $\begin{array}{l}0 \\
0\end{array}$ & $\begin{array}{l}1 \\
3\end{array}$ & $\begin{array}{l}0 \\
0\end{array}$ \\
\hline Mexico & & Before & 1959 & $1959-60$ & $1961-62$ & $1963-64$ & $1965-71$ \\
\hline $\begin{array}{l}\text { Motor Vehicles } \\
\text { Parts }\end{array}$ & $\begin{array}{r}3 \\
10\end{array}$ & & $\begin{array}{l}0 \\
1\end{array}$ & $\begin{array}{l}1 \\
3\end{array}$ & $\begin{array}{l}0 \\
0\end{array}$ & $\begin{array}{l}2 \\
4\end{array}$ & $\begin{array}{l}0 \\
2\end{array}$ \\
\hline
\end{tabular}

Source: NBER company questionnaires. Local content legislation was enacted in 1956 in Brazil, 1958 in Argentina, and in 1962 in Mexico. 
for products that were made in Brazil (Gordon and Grommers, 1962). In Argentina, eight out of seventeen affiliates, in Brazil, eleven out of nineteen, and in Mexico, six out of thirteen were established within four years or less after the enactment of local content legislation. The fact that these were not the same years in all countries suggests that the concentration in time does not reflect simply developments in the U.S. or in the parent companies.

The concentration in time of these beginnings of manufacturing production are also revealed in a more comprehensive set of data summarized in Table 5. The Brazilian share of new U.S.-owned manufacturing subsidiaries in the motor vehicles and equipment industry rose from 4 per cent in all the years before 1951 to 21 per cent in 1956-59, just after the establishment of the program described above. The share of Argentina reached a peak of 15 per cent in 1960-63 and that of Mexico a peak of 75 per cent in 1956-59. The timing of entry seems to be closely associated with the enactment of local content regulation.

To summarize these results, we can say that local content regulations applied to affiliates of auto companies seem to have increased the probability that a U.S. auto company or a U.S. parts company would locate a manufacturing affiliate in a country. The effect seems to have been somewhat stronger in developing countries than in Europe. Larger market size raised the probability of entry by both auto and parts affiliates. The fact that a country was an LDC decreased the probability for both, while higher per capita income increased it, even among LDC's. Also, larger market size and being an LDC significantly increased the probability that local content regulations were in force in a country. 


\section{TABLE 5}

Dates of First Manufacturing by Foreign Subsidiaries of U.S. Companies Motor Vehicles and Equipment (SITC 371)

\begin{tabular}{|c|c|c|c|c|c|c|c|}
\hline & \multicolumn{4}{|c|}{ Number } & \multicolumn{3}{|c|}{$\begin{array}{l}\text { Per Cent of Total } \\
\text { Outside U.S. }\end{array}$} \\
\hline & U.S. & Argentina & Braz11 & Mexico & Argentina & Brazil & Mexico \\
\hline Pre-1951 & 75 & 2 & 3 & 2 & 3 & 4 & 3 \\
\hline $1951-55$ & 15 & 1 & 2 & 1 & 7 & 13 & 7 \\
\hline $1956-59$ & 48 & 5 & 10 & 7 & 10 & 21 & 15 \\
\hline $1960-63$ & 75 & 11 & 3 & 6 & 15 & 4 & 8 \\
\hline $1964-67$ & 81 & 5 & 4 & 7 & 6 & 5 & 9 \\
\hline
\end{tabular}

Source: Vaupel and Curhan (1969), p. 227. 


\section{b. The Level of Affiliate Activity}

In an earlier study of influences on the foreign activity of U.S. firms (Lipsey and Weiss, 1976), net sales or net fixed assets of U.S. affiliates were related to various measures of market size, foreign (non-U.S.) affiliate activity, distance from the United States and Europe, and EEC membership. It was found that the only consistent influence on U.S. affiliate activity in the auto and truck industry in developed countries was the size of the market, as represented by GDP or imports of all manufactures. In some equations, EEC membership was a significantly negative influence. The presence of non-U.S.-owned auto and truck affiliates and distance from the United States and Germany had no visible effect. In the parts industry, size of market again was a positive and significant influence on U.S. affiliate activity, but there was also a positive relationship with the presence of foreign-owned manufacturing affiliates and, In the best equations, a negative influence of distance from the United States. Distance from Germany and EEC membership had no apparent influence. The positive market size coefficients were interpreted as reflecting economies of scale, since the developed-country markets were not segregated from each other and there was, therefore, no need to manufacture in a large country to have a market there. The positive relation of U.S. to foreign affiliate activity might have represented some degree of rivalry for markets between firms in the United States and those in other countries or differences in government policies that encouraged both United States and non-U.S. affiliates or discouraged both, although the latter is a more likely explanation for the developing countries. 
In the developing countries Lipsey and Weiss found little to explain U.S. affiliate activity. Only the extent of foreign affiliate activity seemed to have any relation to the level of U.S. affiliate activity, and that was a positive one. Within this group of countries this relation probably reflected government policy more than anything else.

Thus, of the variables mentioned earlier, market size appeared to have been the main influence on the level of activity of U.S. affiliates in the motor vehicles and parts industries, at least in the developed countries, and we believe this relationship reflected the influence of economies of scale. U.S. parts companies were apparently motivated by both rivalry with foreign producers and possibly by governmental regulations, such as domestic content requirements, not included in these equations, to be more active in countries where foreign-owned parts producers were located.

We would expect that the level of activity a firm would choose for its affiliates in a country, given the initial decision to invest there, would be a function of the size of the market, the average income level there, whether the country is an LDC (unless that characteristic is completely identified by average income), the existence of various regulations on and subsidies for operations there, and the length of time the company had been operating in that country. The general relationship is described by:

(6) $\operatorname{NFAS}_{i j}=f\left(\mathrm{GDP}_{i}, \mathrm{GDPC}_{i}, \mathrm{LDC}_{i}, \mathrm{REGl}_{i}, \mathrm{REG}_{i}, \mathrm{YRSAV}_{i j}\right)$

where, aside from variables described earlier:

$$
\begin{aligned}
& \text { NFAS }_{i j}=\text { the "activity" variable which is total net sales in country } i \\
& \text { of all affiliates of any parent } j \text { investing in country } i \text {, minus all }
\end{aligned}
$$


imports, including those from its parent, those from other affiliates within the firm and those from unaffiliated foreign enterprises. It is similar to local value-added or, more accurately, local activity. This is somewhat broader than value added, since it includes not only value added within the affiliate but also purchases from other producers within the host country, including other U.S. affiliates. A variant is net local sales (NLFAS), net of all imports. These are sales in the host country, excluding exports, net of all imports related to host-country sales, which are estimated as total imports multiplied by the ratio of local to total sales. Other variants are net sales of manufacturing affiliates (NFASM) and sales affiliates (NFASAL) separately.

YRSAV $_{i j}=$ the average date of establishment of all of parents $j$ 's affiliates in country $i$.

We expect a negative relationship between the date-ofestablishment and activity variables since the longer a company has been in the market of a particular country, the better it knows the market and the longer it has had time to acquire brand recognition and acceptance. Since the variable is not the age of the affiliate but rather the date of establishment, the negative coefficient for date represents a positive relationship with age.

GDP $_{i}=$ Gross Domestic Product of country $i$. We expect a positive relationship between market size and the level of activity. GDPC $_{i}=$ Gross Domestic Product per capita of country 1 , either as a proxy for wage level, in which case we would expect a negative rela- 
tionship with affiliate activity, or as a proxy for development of infrastructure, in which case we would expect a positive relationship.

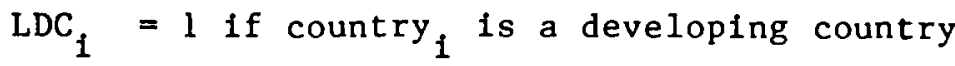

$=0$ otherwise

We expect a negative relationship between the level of activity chosen and the characteristic that a country is an LDC.

REGl $_{i}=1$ if country $i$ has local content requirements.

$=0$ otherwise

Here we are not quite sure what to expect. Even if local content requirements encourage entry, it is not clear how they affect the level of activity once an affiliate locates in a country. REG2 $_{i}=1$ if country $i$ offers investment incentives such as tariff concessions or subsidies.

$=0$ otherwise

We expect investment incentives, since they lower costs to the affiliate, to encourage larger size of operations.

Affiliates located in Europe and those located in the LDC's were treated separately. The two areas are dissimilar not only in terms of the levels of development, but also in terms of the extent of government intervention. Europe, especially the EEC, can be looked at as offering something closer to what one could consider one large market for prospective investors. Economies of scale could be realized and intra-firm trade rationalized. Affiliates in one country could specialize in one particular model or component and trade with affiliates specialized in other models or 
components in other countries. The potential for this type of utilization of economies of scale may have influenced both the dectsion to locate and the level of activity chosen.

Although our main interest is in manufacturing activity, rather than in sales, research, or service operations, we did run some equations in which the dependent variable was the net sales of all affiliates of auto companies. The speculation behind those calculations was that sales affiliates, for example, were not a clearly distinct class from manufacturing affiliates but that affiliates were on a continum from those that only handled sales to those that assembled cars from wholly or partly imported components to those that manufactured complete cars. Since manufacturing activities would have high ratios of net sales to total sales and sales activities low ratios, we thought that our net sales variable might be a good proxy for the amount of manufacturing activity. If that had been the case, we should have been able to explain net sales of all affiliates better than net sales of only those classified as manufacturing. This did not turn out to be the case, probably because sales and service activities do require very substantial value added. We therefore report mainly the equations for activity of affiliates characterized as manufacturing, shown in Table B-1, although we refer to those for all affiliates, in Table B-2, with their greater numbers of observations, for some slightly different results.

In the equations for all countries, only two variables consistently and significantly affected the level of activity of manufacturing affiliates of individual U.S. auto companies: market size and the presence of local content requirements, the latter a negative influence. There were weak indications of 
the possible influence of two other variables: date of establishment and country per capita income. The longer a company's affiliates had been established in a country, the higher their level of production. Production was also larger in countries with higher per capita incomes, suggesting that this variable was acting as a proxy for stage of development rather than for the price of labor. Identification of a country as developing had no significant relation to output, whether or not income per capita was included in the equation.

If we look at Europe and the developing countries separately, at the cost of limiting the numbers of observations, we are more successful in explaining manufacturing activity in Europe. Market size was clearly a positive influence. Less consistently, period since establishment was associated with higher production and local content requirements with lower production. In the developing countries, while the signs of the coefficients were the same, only market size was a significant variable. The positive relation between per capita income and affiliate activity vanished completely when Europe and the developing countries were separated, a further indication that the coefficient in the worldwide equation represented the effect of the level of development.

The levels of activity for all affiliates are much less well explained than those for manufacturing affiliates across all countries. The positive influence of period since establishment is more consistently significant, but no negative influence of local content requirements is visible. However, investment incentives appear here to have had a strong positive influence on activity. Within Europe, only market size and period since establishment were significant influences, and among developing countries only market size.

The most important result here is that we can find no evidence that local 
content regulation increased the level of a U.S. affiliate's manufacturing activity in a country. It may even have reduced it by increasing production cost. In combination with the earlier result that such regulation increased the probability of entry, the implication appears to be that local content regulations increased the number of U.S. firms in a country imposing them but tended to reduce their average scale of operations, if it had any effect at all on scale. In other words, it fragmented production among larger numbers of units, perhaps smaller and presumably less efficient ones. A longer period of operations in a country seems to have added to a firms's level of output, perhaps through the increase in local familiarity with its products. There is some slight evidence that investment incentives increased output, but the effect is only visible for affiliates in general, a fact which suggests that it operated mainly on affiliates classified as non-manufacturing.

Overall, then, we seem to find that while there was some evidence that domestic content regulation increased the probability of investment and production in a country by U.S. auto firms, we could see little indication of significant effects of these regulations on the average level of activity. Measures of market size alone explained the scale of manufacturing affiliate activity quite well, especially in developing countries.

We assume that parts company affiliate activity was determined largely by the same variables used for auto company activity. The only variable NFAS $=f(G D P$, GDPC, LDC, REG1, REG2, YRSAVI, ANFAS $)$ different from those discussed in the case of automobile company affiliate activity is the ANFAS variable which is the aggregate level of activity of 
all automobile company affiliates in a country. We expect parts company affiIiate activity to have been positively related to the level of activity of automobile company affiliates.

We had less success in explaining the levels of activity of affiliates of U.S. parts producers than of auto company affiliates. None of the hypothesized influences seemed to have any effect on activity levels in Europe. In developing countries, the strongest influence, and the only consistently significant one, was the level of activity of U.S. auto company affiliates in the aggregate. However, aggregate auto company affiliate activity in developing countries was so strongly correlated with market size $\left(\mathrm{r}^{2}>.80\right)$ that we cannot distinguish clearly between them as influences on parts company affiliate location. The parts companies do appear to have been drawn to developing countries by the auto companies but to have located in Europe for reasons other than the individual country characteristics we include. As we expected, the size of individual country markets and auto company location were not important in Europe; the parts companies were apparently able to treat Europe as a single market.

The contrast between the apparent success of local content regulation in inducing entry and its lack of influence on the amount of a company's production and local purchases given that the firm was already operating in that country may be a confirmation of the analysis in Dixit and Grossman (1982). They expected local content requirements to expand the range of processes performed in the country, a phenomenon that may be reflected in the increase in the number of auto and parts manufacturing affiliates, but not necessarily to increase output. The anti-protective effect is asso- 
ciated in their paper with low elasticity of factor substitution. A low elasticity of substitution between labor and physical capital in the motor vehicle industry was found in an analysis of factor substitution within multinational firms (Lipsey, Kravis, and Roldan, 1982) in data for 1966 from a complete census of U.S. direct investment abroad, but not in 1970 data from a sample of large companies.

\section{TOBIT Analysis of Affiliate Activity Levels}

If we expand our analysis to include observations for no location, that is, where the level of activity of a firm in a country could be ' 0 ', we are then dealing with a censored sample in which data are clustered at a limit, and therefore use TOBIT analysis. 4

As in the LOGIT, we have four observations for each country: the decisions of each of the four auto companies to locate or not locate in that country. If a firm does locate in a country we do not in this case record that simply as a yes response but look at the level of net sales for the affiliates of that firm in that country.

We define $I_{\mathbf{i j}}{ }^{*}$, our level of desired or potential level of affiliate activity as

$$
I_{i j}^{*}=\alpha_{1} W_{i}+\alpha_{2} M_{i}+\alpha_{3} L_{i}+\alpha_{4} R_{i} E_{i}+E_{i}
$$

and define our model as

$$
\begin{aligned}
& I_{i j}=I_{i j}{ }^{*} \text { if } I_{i j}{ }^{*}>0 \\
& I_{i j}=0 \text { otherwise }
\end{aligned}
$$

The results of these calculations are presented in Appendix Tables $\mathrm{C}-1$ and $\mathrm{C}-2$, the first confined to affiliates classified as manufacturing and the second

${ }^{4}$ Although TOBIT analysis assumes a normal rather than logistic (as was assumed for the LOGIT) cumulative distribution of the error terms, the two
distributions produce empirical results which are very similar. 
including all affiliates.

We find, again, a very strong and consistent influence of market size, as measured by real GDP. The larger the market, the higher the affiliate production. Within Europe, that was the only clearly important influence on a firm's production level.

Among developing countries, three other variables were almost always significant. The higher a country's per capita income, the higher the affiliate production. If the per capita income was not included in the equation, classification of a country as developing was associated with lower average affiliate output, and that classification appeared to have some negative effect in the equations for all types of affiliates, even if per capita income was accounted for.

The existence of local content regulation appeared to raise aggregate affiliate output in developing countries, even though earlier results suggested that it did not increase the average scale of any one company's operations. This result presumably reflects the influence of local content regulations in inducing production by firms that would otherwise not have entered these markets. 5

To the extent that the regulations induced entry at sub-optimal levels of operation for individual firms, there may have been some penalty in the form of high costs of production paid by host-country residents (see, for example, Munk,

5 In the TOBIT, the expected value of all observations can be decomposed into "the expected value conditional upon being above the limit and the probability of being above the limit" (McDonald \& Moffitt 1980). Since our limit observations tend to be at least $50 \%$ of the sample (sometimes $80 \& 90 \%$ ) it is not surprising that the total effect of local content regulation on activity was a positive one. The positive effect of local content regulations on entry dominated the zero or negative effect of these regulations on scale. 
1969). We tried to find some evidence of this in the data on prices of motor vehicles relative to other goods and services from Kravis, Heston, and Summers (1982). However, while there were wide disparities among countries in motor vehicle prices, they were explained mainly by per capita income, or better, by whether the country was listed as developing, and by a dummy variable for the existence of a motor vehicle manufacturing industry. Developed countries had far lower relative prices for motor vehicles and, given per capita income or stage of development, countries with motor vehicle industries also had lower prices. Dummy variables for local content requirements showed coefficients that were positive but far from being significant. The lower prices in countries with motor vehicle production, despite the likely inefficiency of much of that production, suggest that prices paid by consumers were determined more by tax rates than by costs of production or importing.

\section{SUMMARY}

The world market for motor vehicle and parts has been the object of government interventions for the last 50 years to a greater degree than most manufactured products. Those interventions, particularly those in favor of small cars, were one cause of the split between the kinds of cars produced in Europe and those produced in the U.S. and Canada. That segmentation of the world market probably insured that U.S. companies, even in 
their years of greatest technological leadership, would serve European markets largely through production there rather than by exporting. However, that development might have come eventually in any case.

Beginning in the 1950's and 1960's developing countries began much more active efforts to force the establishment of local motor vehicle industries. Since this is an industry in which economies of scale are important, the establishment of local industries could impose high costs on local consumers, and there have been many examples of uneconomic production. Multinational companies adapted to extremely low levels of production in some countries by importing most components and limiting local activity to assembly. Where local content requirements were increased, the companies tended first to take advantage of the differences in economical scale levels for different parts of their products, beginning local production or purchasing with those for which economical production could be achieved at the lowest levels. When higher levels of local content were enforced, the companies moved toward negotiating arrangements to offset imports by exports, achieving what scale economies they could then by having plants in different countries specialize in different parts of the vehicles and export to other countries. We have tried here to observe the extent and nature of that adaptation, concentrating on such variables as size of markets, levels of production, and government interventions such as local content requirements and investment incentives. The results are summarized in Table 6.

The probability that a U.S. auto company would carry out some manufacturing, including assembly, in a country was a function of market charac- 
Table 6

Signs of Coefficients ${ }^{a}$ for Main Location Variables

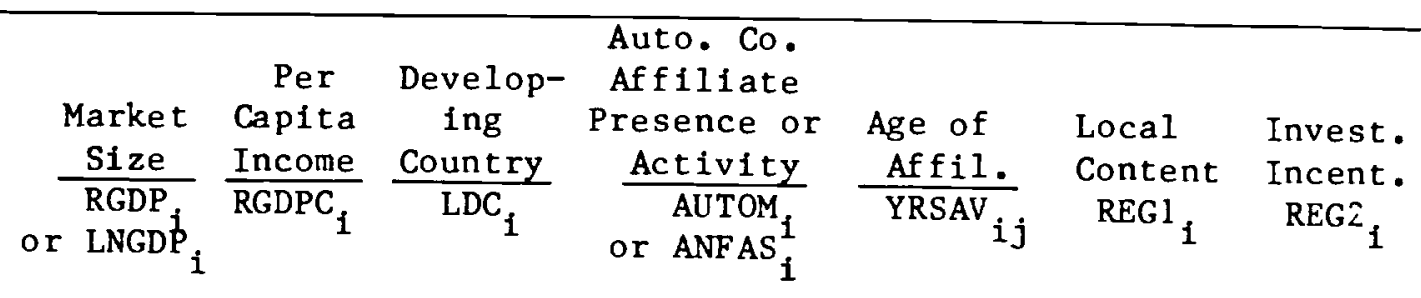

Probability of Entry (LOGIT)

Auto affiliates: All countries ++

Europe

Developing countries (t) +

Parts manufacturing affiliates +

Probability of REG1 (LOGIT)

Level of Activity of Existing Affiliates (OLS)

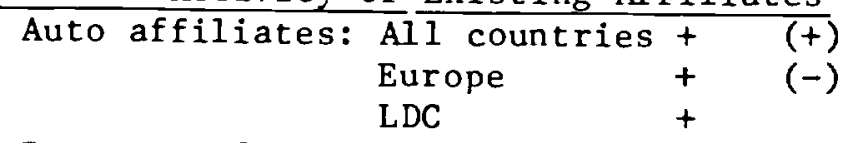

LDC

$(+)$

LDC

$\frac{\text { Level of Activity of All Affiliates (TOBIT) }}{+}$

Europe

Developing countries
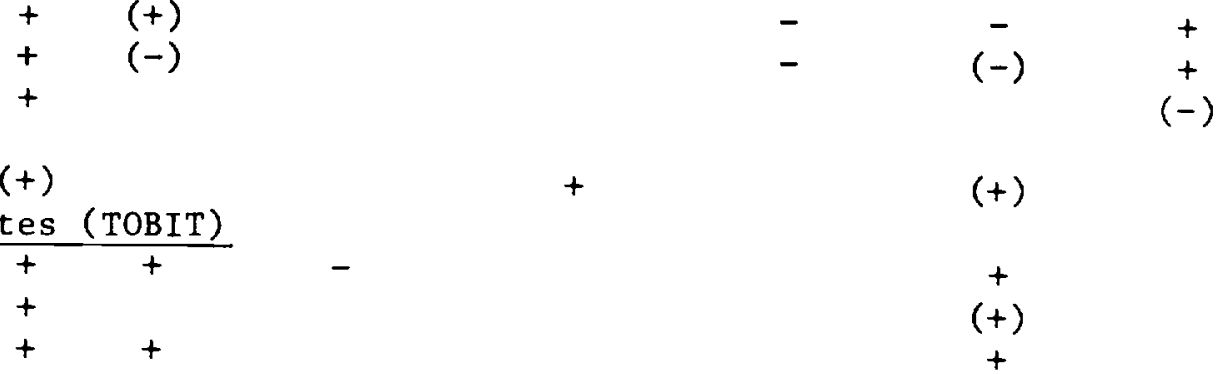

${ }^{a}$ Coefficients with t-statistics $\geq 1$. Those with t-statistics $\geq 1$ but $<2$ are in parentheses.

Source: Tables $A-1, A-2, B-1, B-2, B-3, C-1$, and $C-2$. 
teristics such as aggregate and per capita income. The probability of entry also seemed to be increased by the presence of local content requirements. The probability of entry by manufacturing affiliates of U.S. parts companies was determined by market size and the presence of a U.S. auto company manufacturing affiliate, both of which had positive effects. Per capita income and the existence of local content requirements on auto producers appeared to influence parts company affiliate location only through their effects on auto affiliate entry. A strong link between the enactment of local content requirements, the entry of U.S. auto companies, and entry by U.S. parts companies is also suggested by the time series data.

We distinguished between the probability of entry and the extent of affiliate production, both for those affiliates that were operating (a measure of the average scale of production) and for all potential affiliates (an indicator of aggregate production). The scale of production of existing auto and parts company affiliates was to a large extent a function of market size and, for parts producers, the extent of the activity of U.S. auto affiliates. We could find no evidence that local content requirements increased the scale of host-country output of cars by U.S. affiliates. In fact, it appeared that local content requirements may have led to lower scales of output by U.S. auto affiliates, although evidence for this is weak. There are signs, but only weak ones, that the levels of output of auto affiliates in Europe were increased by the presence of investment incentives. Since investment incentives are cost-reducing while local content requirements are cost-increasing, there is some logic to this outcome.

Auto company affiliate output, but not that of parts company affi- 
liates, was higher, the earlier the date of establishment of the affiliate. That fact suggests that auto companies, selling mainly to consumers, gained market share from a long period of acqualnting consumers with a company's name and products, while parts companies, selling mainly to producers, did not. The parts producers may have been able to draw on their customers' experience with them in other countries, as auto producers could not. It appears that at least the developing countries, and possibly some European countries, were able to increase the levels of local output by firms in general - that 1s, aggregate local output - through local content requirements. The penalty was apparently that the production by each individual firm was at a scale below the optimum, with the probable result, although we have no direct evidence, that costs of production were higher. 


\section{References}

Baranson, Jack (1969), Automotive Industries in Developing Countries, World Bank Staff Occasional Papers No. 81969.

Buckley, Peter J. and Mark Casson (1976), The Future of the Multinational Enterprise. London, Macmillan.

Caves, R.E. (1971), "International Corporations: The Industrial Economics of Foreign Investment," Economica, 38, pp. 1-27.

(1974), "Industrial Organization." In J.H. Dunning (ed.), Economic Analysis and the Multinational Enterprise, pp. 115-46. London: George Allen \& Unwin.

(1982), Multinational Enterprise and Economic Analysis. Cambridge, MA: Cambridge University Press.

Dixit, Avinash K., and Gene M. Grossman (1982), "Trade and Protection with Multistage Production," Review of Economic Studies, XLIV, pp. 583-94.

Dunning, J.H. (ed.) (1971), The Multinational Enterprise. London: George Allen \& Unwin.

(ed.) (1974), Economic Analysis and the Multinational Enterprise. London: George Allen \& Unwin.

Gordon, Lincoln, and Engelbert Grommers (1962), United States Manufacturing Investment in Brazil. Boston: Harvard University, Graduate School of Business Administration.

Horst, T. (1974), "American Exports and Foreign Direct Investments," Harvard Institute of Economic Research Discussion Paper No. 362, May.

Kravis, Irving B., Alan Heston, and Robert Summers (1978), "Real Per Capita Income for More than One Hundred Countries," Economic Journal, 88, No. 350 , June.

(1980), "International Comparison of Real Product and its Composition: 1950-77," Review of Income and Wealth, Series 26, No. 1, March.

(1982), World Product and Income, UN International Comparison Project, Phase III. Baltimore and London: Johns Hopkins University Press for the World Bank.

Kravis, Irving B., Zoltan Kenessey, Alan Heston, and Robert Summers (1975), A System of International Comparisons of Gross Product and Purchasing Power, UN International Comparison Project, Phase I. Baltimore and London: Johns Hopkins University Press for the World Bank.

Kravis, Irving B., and Robert E. Lipsey (1971), Price Competitiveness in World Trade. National Bureau of Economic Research. 
Lipsey, Robert E., and Irving B. Kravis (1982), "U.S.- Owned Affiliates and Host-Country Exports," National Bureau of Economic Research, Working Paper 1037, December.

Lipsey, Robert E., Irving B. Kravis, and Romualdo A. Roldan, "Do Multinational Firms Adapt Factor Proportions to Relative Factor Prices?", in Anne 0. Krueger (ed.), Trade and Employment in Developing Countries, 2: Factor Supply and Substitution. Chicago: University of Chicago Press for the NBER.

Lipsey, Robert E., and Merle Yahr Weiss (1976), Exports and Foreign Investment in Manufacturing Industries. National Bureau of Economic Research, Working Paper 131, March.

Magee, S.P. (1977), "Information and Multinational Corporations: An Appropriability Theory of Direct Foreign Investment." In J. Bhagwati (ed.), The New International Economic Order, pp. 317-40. Cambridge, MA: M.I.T. Press.

Maxcy, George, and Aubrey Silberston (1959), The Motor Industry. London: George Allen \& Unwin.

(1981), The Multinational Auto Industry. New York: St. Martin's Press.

McDonald, John F., and Robert A. Moffitt (1980), "The Uses of Tobit Analysis," Review of Economics and Statistics, Vol. LXII, No. 2, May.

Munk, Bernard (1969), "The Welfare Costs of Content Protection: The Automotive Industry in Latin America," Journal of Political Economy, 77, No. 1, Jan/Feb.

Picard, Fernand L. (1970), "The Rationale of the Gradual Development of the Automobile Industry from Assembly of Imported Parts to Complete Local Production," in United Nations, Establishment and Development of Automotive Industries in Developing Countries, Vol. II, Proceedings of the Seminar.

Robinson, Richard D. (1983), Performance Requirements for Foreign Business: U.S. Management Response. New York: Praeger.

Southard, Frank A. (1931), American Industry in Europe. Boston: Houghton Mifflin Co.

U.S. Department of Commerce (1953), Direct Private Foreign Investments of the United States, Census of $19 \overline{50}$. Office of Business Economics.

(1960), U.S. Business Investments in Foreign Countries, by Samuel Pizer and Frederick Cutler, Office of Business Economics. 
(1975), U.S. Direct Investment Abroad, 1966,

Bureau of Economic Analysis.

(1980), Survey of Automotive Trade Restrictions

Maintained by Selected Nations, June.

Bureau of Economic Analysis.

(1981), U.S. Direct Investment Abroad, 1977,

(1983), An Analysis of Automotive Local Content Laws in Other Countries, International Trade Administration, October.

U.S. Department of the Treasury (1982), Policies and Practices Relating to Investment: Government Restrictions and Incentives, Office of International Investment.

Vaupel, James W., and Joan P. Curhan (1969), The Making of Multinational Enterprise. Boston: Harvard University, Graduate School of Business Administration.

Wilkins, Mira, and Frank Ernest Hill (1964), American Business Abroad: Ford on Six Continents. Detroit: Wayne State University Press. 
</ref_section> 
Table A-1

Coefficients of LOGIT Equations for Presence of Auto Affiliates

Independent Variables

Eq. Dependent

$\begin{array}{llllll}\mathrm{RGDP}_{\mathbf{i}} & \mathrm{LNGDP}_{\mathbf{i}} & \mathrm{RGDPC}_{\boldsymbol{i}} & \mathrm{LDC}_{\mathbf{i}} & \mathrm{REGl}_{\mathbf{i}} & \text { No. }\end{array}$

ALL COUNTRIES

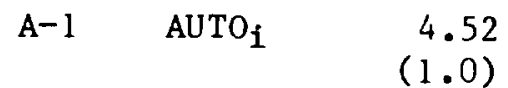

A-2 $\quad$ " $\quad 3.15$

$(0.7)$

$\begin{aligned} A-3 \quad & 12.79 \\ & (2.3)\end{aligned}$

A-4 $\quad \cdot$

A-5 $\quad \cdot$

$\mathrm{A}-7 \quad$

$\mathrm{A}-6 \quad$ -

3.69

$(0.6)$

$(2.1)$

3.16
$(4.0)$

92

DEVELOPING COUNTRIES

.38
$(1.8)$

$\begin{array}{rr}.20 & .71 \\ (0.9) & (4.2)\end{array}$
2.22
$(2.9)$

117

117

38 at 1

117

117

$(2.2)$

$\begin{array}{ll}-3.00 & 1.70 \\ (4.2) & (2.3)\end{array}$

117

$(4.2) \quad(2.3)$
17 at 1

92
$-.36$
.53
3.92
(3.5)
(1.2) (2.3)

ALL COUNTRIES

\begin{tabular}{|c|c|c|c|c|c|c|}
\hline$A-8$ & $\operatorname{AUTOM}_{i}$ & $\begin{array}{r}1.94 \\
(0.7)\end{array}$ & & $\begin{array}{l}-1.7 \\
(2.3)\end{array}$ & $\begin{array}{c}3.2 \\
(4.9)\end{array}$ & 117 \\
\hline$A-9$ & ". & $\begin{array}{l}1.38 \\
(0.5)\end{array}$ & $\left(\begin{array}{l}.36 \\
(1.7)\end{array}\right.$ & $\begin{array}{l}-0.65 \\
(0.7)\end{array}$ & $\begin{array}{r}3.45 \\
(4.9)\end{array}$ & 117 \\
\hline$A-10$ & " & & & $\begin{array}{r}-1.39 \\
(1.9)\end{array}$ & $\begin{array}{l}2.66 \\
3.6\end{array}$ & 117 \\
\hline
\end{tabular}

()$=$ asymptotic $t$-test 
Table A-1 (cont.)

Independent Variables

\begin{tabular}{|c|c|c|c|c|c|c|c|}
\hline $\begin{array}{l}\text { Eq. } \\
\text { No. }\end{array}$ & $\begin{array}{l}\text { Dependent } \\
\text { Variable }\end{array}$ & $\mathrm{RGDP}_{\mathbf{i}}$ & $\operatorname{LNGDP}_{i}$ & $\mathrm{RGDPC}_{\mathbf{i}}$ & $\mathrm{LDC}_{\mathbf{i}}$ & $\mathrm{REG}_{1}$ & $\begin{array}{l}\text { No. } \\
\text { Obs. }\end{array}$ \\
\hline & \multicolumn{7}{|c|}{ DEVELOPING COUNTRIES } \\
\hline$A-11$ & $\operatorname{AUTOM}_{\mathbf{i}}$ & $\begin{array}{r}.17 \\
(0.0)\end{array}$ & & & & $\begin{array}{r}3.15 \\
(3.7)\end{array}$ & $\begin{array}{l}92 \\
12 \text { at } 1\end{array}$ \\
\hline$A-12$ & $"$ & $\begin{array}{r}.18 \\
(0.0)\end{array}$ & & $(2.52)$ & & $\begin{array}{r}3.32 \\
(3.6)\end{array}$ & 92 \\
\hline \multirow[t]{2}{*}{$A-13$} & $"$ & & $\begin{array}{r}.40 \\
(1.1)\end{array}$ & & & $\begin{array}{r}2.23 \\
(2.1)\end{array}$ & 92 \\
\hline & \multicolumn{7}{|c|}{ ALL COUNTRIES } \\
\hline$A-14$ & $\mathrm{AUTO}_{\mathbf{i j}}$ & $\begin{array}{r}3.18 \\
(2.3)\end{array}$ & & & $\begin{array}{l}-2.2 \\
(7.4)\end{array}$ & $\begin{array}{l}1.4 \\
(4.5)\end{array}$ & $\begin{array}{r}468 \\
84 \text { at l }\end{array}$ \\
\hline$A-15$ & $"$ & $\begin{array}{l}2.13 \\
(1.5)\end{array}$ & & $\begin{array}{l}.506 \\
(5.3)\end{array}$ & $\begin{array}{l}-.76 \\
(2.0)\end{array}$ & $\begin{array}{c}1.8 \\
(5.4)\end{array}$ & 468 \\
\hline$A-16$ & $"$ & & $\begin{array}{l}.33 \\
(2.9)\end{array}$ & $\begin{array}{l}.541 \\
(6.4)\end{array}$ & & $\begin{array}{c}1.4 \\
(3.6)\end{array}$ & 468 \\
\hline$A-17$ & $"$ & & $\begin{array}{l}.48 \\
(4.4)\end{array}$ & & $\begin{array}{l}-1.81 \\
(5.8)\end{array}$ & $\begin{array}{l}.66 \\
(1.9)\end{array}$ & 468 \\
\hline \multirow[t]{2}{*}{$A-18$} & $"$ & & $(2.8)$ & $\begin{array}{l}.425 \\
(4.2)\end{array}$ & $\begin{array}{r}-.77 \\
(2.0)\end{array}$ & $\begin{array}{r}1.31 \\
(3.4)\end{array}$ & 468 \\
\hline & \multicolumn{7}{|c|}{ DEVELOPING COUNTRIES } \\
\hline$A-19$ & $"$ & $\begin{array}{l}1.63 \\
(0.5)\end{array}$ & & & & $\begin{array}{r}2.60 \\
(5.5)\end{array}$ & $\begin{array}{r}368 \\
32 \text { at } 1\end{array}$ \\
\hline$A-20$ & $"$ & $\begin{array}{r}1.84 \\
(0.6)\end{array}$ & & $(4.0)$ & & $\begin{array}{r}2.73 \\
(5.5)\end{array}$ & 368 \\
\hline$A-21$ & $"$ & & $\begin{array}{l}.066 \\
(0.3)\end{array}$ & & & $\begin{array}{c}2.53 \\
(3.9)\end{array}$ & 368 \\
\hline$A-22$ & 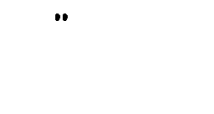 & & $\begin{array}{l}-.124 \\
(0.6)\end{array}$ & $\begin{array}{r}.54 \\
(3.8)\end{array}$ & & $\begin{array}{r}3.14 \\
(4.6)\end{array}$ & 368 \\
\hline
\end{tabular}


Table A-1 (cont.)

Independent Variable

Eq. Dependent RGDP $\mathbf{i} \quad \operatorname{LNGDP}_{\mathbf{i}} \quad \mathrm{RGDPC}_{\mathbf{i}} \quad \mathrm{LDC}_{\mathbf{i}} \mathrm{REGl}_{\mathbf{i}} \quad$ No.

No. Variable Obs.

\begin{tabular}{|c|c|c|c|c|c|c|}
\hline$A-23$ & $\operatorname{AUTOM}_{\mathbf{i j}}$ & $\begin{array}{r}2.22 \\
(1.3)\end{array}$ & $\begin{array}{l}.509 \\
(3.6)\end{array}$ & $\begin{array}{c}.46 \\
(0.9)\end{array}$ & $\begin{array}{r}3.64 \\
(7.2)\end{array}$ & $\begin{array}{r}468 \\
46 \text { at } 1\end{array}$ \\
\hline $\mathrm{A}-24$ & •" & $\begin{array}{r}4.51 \\
(3.2)\end{array}$ & & $\begin{array}{c}-.82 \\
(2.2)\end{array}$ & & 468 \\
\hline$A-25$ & $"$ & $\begin{array}{r}4.15 \\
(2.9)\end{array}$ & $\begin{array}{l}.188 \\
(1.8)\end{array}$ & $\begin{array}{l}-.21 \\
(.41)\end{array}$ & & 468 \\
\hline$A-26$ & $"$ & $\begin{array}{r}4.31 \\
(2.9)\end{array}$ & & & $\begin{array}{r}3.17 \\
(7.3)\end{array}$ & 468 \\
\hline$A-27$ & $"$ & $\begin{array}{r}2.03 \\
(1.2)\end{array}$ & $\begin{array}{r}.431 \\
(3.9)\end{array}$ & & $\begin{array}{r}3.56 \\
(7.3)\end{array}$ & 468 \\
\hline$A-28$ & " & $\begin{array}{r}3.31 \\
(2.1)\end{array}$ & & $\begin{array}{c}-.77 \\
(2.0)\end{array}$ & $\begin{array}{r}3.16 \\
(7.2)\end{array}$ & 468 \\
\hline
\end{tabular}

A-29 $\quad *$

$\mathrm{A}-30 \quad \cdots$
8.71

$(2.5)$
2.01

$(2.8)$

84

(2.7)

-.252
$(.8)$
14 at 1

84 
Table A-1 (cont.)

Independent Variables

\begin{tabular}{|c|c|c|c|c|c|c|}
\hline \multirow[b]{2}{*}{$\begin{array}{l}\text { Eq. } \\
\text { No. }\end{array}$} & \multirow{3}{*}{$\begin{array}{l}\text { Dependent } \\
\text { Variable }\end{array}$} & & & & & \\
\hline & & $\operatorname{RGDP}_{\mathbf{1}}$ & $\operatorname{LNGDP}_{1}$ & $\mathrm{RGDPC}_{\boldsymbol{1}}$ & $\operatorname{REG} l_{i}$ & \multirow[t]{2}{*}{$\begin{array}{l}\text { No. } \\
\text { Obs. }\end{array}$} \\
\hline \multicolumn{5}{|c|}{ DEVELOPING COUNTRIES } & & \\
\hline$A-31$ & $\operatorname{AUTOM}_{\mathbf{i j}}$ & & $\begin{array}{l}.982 \\
(5.3)\end{array}$ & $\begin{array}{l}.245 \\
(2.0)\end{array}$ & & $\begin{array}{r}368 \\
24 \text { at } 1\end{array}$ \\
\hline$A-32$ & . & $\begin{array}{l}3.22 \\
(1.0)\end{array}$ & & $\begin{array}{l}.705 \\
(2.9)\end{array}$ & $\begin{array}{r}4.21 \\
(4.9)\end{array}$ & 368 \\
\hline$A-33$ & $"$ & & $(381)$ & & $\begin{array}{r}2.84 \\
(3.4)\end{array}$ & 368 \\
\hline$A-34$ & $"$ & & $\begin{array}{l}.257 \\
(1.0)\end{array}$ & $\begin{array}{l}.659 \\
(3.5)\end{array}$ & $\begin{array}{c}3.9 \\
(4.1)\end{array}$ & 368 \\
\hline \multicolumn{7}{|c|}{ DEVELOPED COUNTRIES } \\
\hline$A-35$ & $"$ & $\begin{array}{l}3.09 \\
(1.7)\end{array}$ & & & $\begin{array}{c}2.69 \\
(4.2)\end{array}$ & $\begin{array}{r}100 \\
21 \text { at } 1\end{array}$ \\
\hline$A-36$ & $"$ & $\begin{array}{l}2.54 \\
(1.3)\end{array}$ & & $\begin{array}{l}.181 \\
(0.8)\end{array}$ & $\begin{array}{r}2.91 \\
(4.1)\end{array}$ & 100 \\
\hline
\end{tabular}




\section{NOTES TO TABLE A-1}

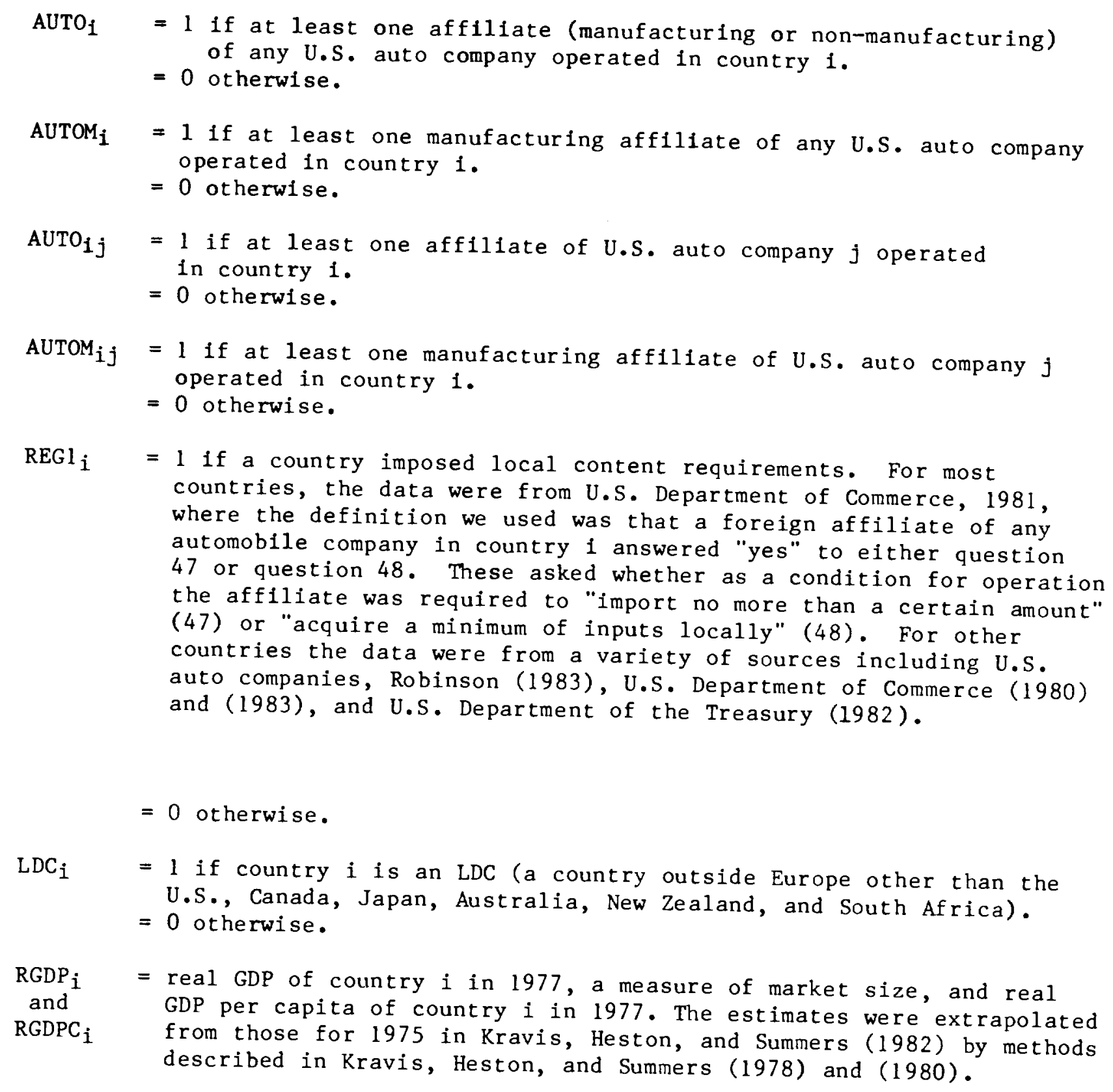
countries, the data were from U.S. Department of Commerce, 1981, where the definition we used was that a foreign affiliate of any automobile company in country 1 answered "yes" to either question 47 or question 48. These asked whether as a condition for operation the affiliate was required to "import no more than a certain amount" (47) or "acquire a minimum of inputs locally" (48). For other countries the data were from a variety of sources including U.S. auto companies, Robinson (1983), U.S. Department of Commerce (1980) and (1983), and U.S. Department of the Treasury (1982).

$=0$ otherwise.

$L_{i} \quad=1$ if country $i$ is an LDC (a country outside Europe other than the U.S. Canada, Japan, Australia, New Zealand, and South Africa).
0 otherwise.

RGDP $_{i}=$ real GDP of country $i$ in 1977, a measure of market size, and real RGDPC $_{i} \quad$ from those for 1975 in Kravis, 1977 . The estimates were extrapolated described in Kravis, Heston, and Summers (1978) and (1980). 
Table A-2

Coefficients of LOGIT Equations for Presence of Parts Company Affiliates

Independent Variables

$\begin{array}{llllllll}\begin{array}{l}\text { Dependent } \\ \text { Variable }\end{array} & \mathrm{RGDP}_{\mathbf{i}} & \mathrm{LNGDP}_{\mathbf{i}} & \mathrm{RGDPC}_{\boldsymbol{i}} & \mathrm{LDC}_{\mathbf{i}} & \mathrm{REGl}_{\mathbf{i}} & \mathrm{AUTOM}_{\mathbf{i}} & \begin{array}{l}\text { No. } \\ \text { Obs. }\end{array}\end{array}$

\begin{tabular}{|c|c|c|c|c|c|c|c|c|}
\hline$A-37$ & $\operatorname{PART}_{1}$ & $\begin{array}{r}5.56 \\
(1.7)\end{array}$ & & & $\begin{array}{l}-1.85 \\
(3.1)\end{array}$ & $\begin{array}{l}.806 \\
(1.3)\end{array}$ & & $\begin{array}{r}118 \\
20 \text { at }\end{array}$ \\
\hline$A-38$ & & & $\begin{array}{l}.487 \\
(2.2)\end{array}$ & & $\begin{array}{l}-1.65 \\
(2.6)\end{array}$ & $\begin{array}{l}.223 \\
(0.3)\end{array}$ & & 118 \\
\hline$A-39$ & & & $\begin{array}{l}.438 \\
(1.9)\end{array}$ & $\begin{array}{l}.343 \\
(2.2)\end{array}$ & & $\begin{array}{l}.554 \\
(0.8)\end{array}$ & & 118 \\
\hline$A-40$ & & & $\begin{array}{l}.459 \\
(2.1)\end{array}$ & & $\begin{array}{l}-1.431 \\
(2.2)\end{array}$ & $\begin{array}{r}-.451 \\
(0.6)\end{array}$ & $\begin{array}{l}1.376 \\
(1.9)\end{array}$ & 118 \\
\hline$A-41$ & & $\begin{array}{l}5.21 \\
(1.6)\end{array}$ & & & $\begin{array}{l}-1.618 \\
(2.6)\end{array}$ & & $\begin{array}{l}1.499 \\
(2.4)\end{array}$ & 118 \\
\hline$A-42$ & & $\begin{array}{l}4.64 \\
(1.4)\end{array}$ & & $(1.1)^{.216}$ & $\begin{array}{l}-1.008 \\
(1.2)\end{array}$ & $\begin{array}{l}.225 \\
(0.3)\end{array}$ & $\begin{array}{l}1.385 \\
(1.9)\end{array}$ & 118 \\
\hline$A-43$ & PARTM $_{\mathbf{i}}$ & $\begin{array}{l}5.42 \\
(1.9)\end{array}$ & & & $\begin{array}{l}-1.34 \\
(1.8)\end{array}$ & $\begin{array}{l}1.43 \\
(2.1)\end{array}$ & & $\begin{array}{r}118 \\
12 \text { at }\end{array}$ \\
\hline A-44 & & $\begin{array}{r}4.69 \\
(1.7)\end{array}$ & & $\begin{array}{l}.343 \\
(1.4)\end{array}$ & $\begin{array}{l}-.367 \\
(0.4)\end{array}$ & $\begin{array}{l}1.7 \\
(2.3)\end{array}$ & & 118 \\
\hline$A-45$ & & & $\begin{array}{l}.865 \\
(2.8)\end{array}$ & & $\begin{array}{l}-.806 \\
(1.03)\end{array}$ & $\begin{array}{l}.478 \\
(0.6)\end{array}$ & & 118 \\
\hline$A-46$ & & & $\begin{array}{l}.878 \\
(2.6)\end{array}$ & & $\begin{array}{l}-.385 \\
(0.5)\end{array}$ & $\begin{array}{l}-.791 \\
(0.8)\end{array}$ & $\begin{array}{l}2.317 \\
(2.4)\end{array}$ & 118 \\
\hline$A-47$ & & $\begin{array}{c}4.76 \\
(1.6)\end{array}$ & & $\begin{array}{r}.241 \\
(0.9)\end{array}$ & $\begin{array}{c}-.256 \\
(0.3)\end{array}$ & $\begin{array}{r}.383 \\
(0.4)\end{array}$ & $\begin{array}{l}2.258 \\
(2.4)\end{array}$ & 118 \\
\hline$A-48$ & & $\begin{array}{l}5.42 \\
(1.9)\end{array}$ & & & $\begin{array}{c}-.831 \\
(1.1)\end{array}$ & $\begin{array}{r}.169 \\
(0.2)\end{array}$ & $\begin{array}{l}2.409 \\
(2.6)\end{array}$ & 118 \\
\hline
\end{tabular}

$\frac{\text { Notes: }}{\text { PART }_{i}} \quad=1$ if at least one affiliate of any U.S. parts manufacturing company operates in country $i$.

$=0$ otherwise.

PARTM $_{i}=1$ if at least one manufacturing affiliate of any U.S. parts manufacturing company operates in country $i$.

$=0$ otherwise. 
Table B-1

Coefficients of OLS Equations For Activity of All Auto Manufacturing Affiliates of U.S. Auto Companies

Dependent Variable: NFASM $_{1 j}$ (AUTO)

\begin{tabular}{|c|c|c|c|c|c|c|c|}
\hline \multirow[b]{2}{*}{$\begin{array}{l}\text { Eq. } \\
\text { No. }\end{array}$} & \multicolumn{5}{|c|}{ Independent Variables } & \multirow[b]{2}{*}{$\overline{\mathrm{R}}^{2}$} & \multirow[b]{2}{*}{$\begin{array}{l}\text { No. } \\
\text { Obs. }\end{array}$} \\
\hline & $(\stackrel{\text { RGDP }}{(\$ \text { bilf. }}$ & $\mathrm{RGDPC}_{1}$ & $\begin{array}{l}\text { DATE }_{j \mathcal{j}} \\
(000)^{\prime}\end{array}$ & REG $1_{1}$ & REG 2 & & \\
\hline \multicolumn{8}{|c|}{ ALL COUNTRIES } \\
\hline B-1 & $\begin{array}{r}5,915 \\
(9.4)\end{array}$ & & $\begin{array}{l}-6.8 \\
(1.9)\end{array}$ & $\begin{array}{r}-595 \\
(3.1)\end{array}$ & & .72 & 45 \\
\hline B-2 & $\begin{array}{r}5,293 \\
(7.4)\end{array}$ & $\begin{array}{l}87.10 \\
(1.7)\end{array}$ & $\begin{array}{l}-4.3 \\
(1.1)\end{array}$ & $\begin{array}{r}-568 \\
(3.1)\end{array}$ & & .73 & 45 \\
\hline B-3 & $\begin{array}{r}6,278 \\
(8.1)\end{array}$ & & $\begin{array}{l}-8.2 \\
(2.0)\end{array}$ & & $\begin{array}{r}-121.2 \\
(0.6)\end{array}$ & .65 & 45 \\
\hline B-4 & $\begin{array}{r}5,580 \\
(6.6)\end{array}$ & $\begin{array}{r}107.1 \\
(1.9)\end{array}$ & $\begin{array}{l}-5.5 \\
(1.3)\end{array}$ & & $\begin{array}{r}-162.0 \\
(0.9)\end{array}$ & .67 & 45 \\
\hline \multicolumn{8}{|c|}{ EUROPE } \\
\hline B-5 & $\begin{array}{l}6,086 \\
(4.2)\end{array}$ & & $\begin{array}{r}-17.1 \\
(1.3)\end{array}$ & $\begin{array}{r}-680 \\
\quad(1.5)\end{array}$ & & .70 & 14 \\
\hline B-6 & $\begin{array}{r}8,181 \\
(3.2)\end{array}$ & $\begin{array}{l}-250 \\
(1.0)\end{array}$ & $\begin{array}{r}-19.4 \\
(1.4)\end{array}$ & $\begin{array}{l}-904 \\
(1.7)\end{array}$ & & .70 & 14 \\
\hline $\mathrm{B}-7$ & $\begin{array}{r}5,466 \\
(2.8)\end{array}$ & & $\begin{array}{r}-26.6 \\
(2.0)\end{array}$ & & $\begin{array}{l}247 \\
(0.4)\end{array}$ & .64 & 14 \\
\hline \multicolumn{8}{|c|}{ DEVELOPING COUNTRIES } \\
\hline$B-8$ & $\begin{array}{l}2,784 \\
(4.9)\end{array}$ & & $\begin{array}{l}-1.4 \\
(1.3)\end{array}$ & $\begin{array}{r}-40.3 \\
(0.34)\end{array}$ & & .52 & 24 \\
\hline$B-9$ & $\begin{array}{r}2,797 \\
(5.4)\end{array}$ & & & & & .55 & 24 \\
\hline$B-10$ & $\begin{array}{r}2,988 \\
(4.7)\end{array}$ & $\begin{array}{r}-42 \\
(0.8)\end{array}$ & $\begin{array}{l}-3.2 \\
(1.3)\end{array}$ & & $\begin{array}{r}-103 \\
\quad(1.0)\end{array}$ & .53 & \\
\hline
\end{tabular}


Table B-2

Coefficients of OLS Equations For Activity of Al1 Auto Affillates of U.S. Auto Companies

Dependent Variable: NFAS $1 j$ (AUTO)

\begin{tabular}{|c|c|c|c|c|c|c|c|}
\hline \multirow[b]{2}{*}{$\begin{array}{l}\text { Eq. } \\
\text { No. }\end{array}$} & \multicolumn{5}{|c|}{ Independent Variables } & \multirow[b]{2}{*}{$\overline{\mathrm{R}}^{2}$} & \multirow[b]{2}{*}{$\begin{array}{l}\text { No. } \\
\text { Obs. }\end{array}$} \\
\hline & $($ RGDP & RGDPC $_{1}$ & $\begin{array}{l}\text { DATE } j \mathrm{j} \\
(000)^{\prime}\end{array}$ & REG $1_{1}$ & REG $2_{1}$ & & \\
\hline & \multicolumn{7}{|c|}{ ALL COUNTRIES } \\
\hline B-1 1 & $\begin{array}{r}2,590 \\
(5.3)\end{array}$ & & $\begin{array}{r}-10.1 \\
(2.9)\end{array}$ & $\begin{array}{l}544 \\
(0.4)\end{array}$ & & .32 & 80 \\
\hline B-1 2 & $\begin{array}{r}2,414 \\
(4.8)\end{array}$ & $\begin{array}{l}49.2 \\
(1.2)\end{array}$ & $\begin{array}{l}-8.9 \\
(2.4)\end{array}$ & $\begin{array}{l}14.2 \\
(1.0)\end{array}$ & & .32 & 80 \\
\hline B-1 3 & $\begin{array}{r}2,309 \\
(4.7)\end{array}$ & & $\begin{array}{l}-7.0 \\
(1.9)\end{array}$ & & $\begin{array}{r}314.8 \\
(2.3)\end{array}$ & .36 & 80 \\
\hline B-14 & $\begin{array}{r}2,160 \\
(4.3)\end{array}$ & $\begin{array}{l}37.2 \\
(4.3)\end{array}$ & $\begin{array}{l}-6.3 \\
(1.7)\end{array}$ & & $\begin{array}{r}329.2 \\
(2.3)\end{array}$ & .36 & 80 \\
\hline
\end{tabular}

EUROPE

\begin{tabular}{|c|c|c|c|c|c|c|}
\hline B-15 & $\begin{array}{c}4,750 \\
(5.7)\end{array}$ & & $\begin{array}{r}-19.8 \\
(3.3)\end{array}$ & $\begin{array}{l}96.8 \\
(0.4)\end{array}$ & & .57 \\
\hline B-16 & $\begin{array}{r}4,430 \\
(5.1)\end{array}$ & $\begin{array}{r}103.7 \\
(1.1)\end{array}$ & $\begin{array}{r}-20.1 \\
(3.3)\end{array}$ & $\begin{array}{r}276.4 \\
(1.0)\end{array}$ & & .58 \\
\hline B-17 & $\begin{array}{r}4,400 \\
(4.8)\end{array}$ & & $\begin{array}{r}-18.1 \\
(2.9)\end{array}$ & & $\begin{array}{l}225 \\
(0.9)\end{array}$ & .58 \\
\hline$B-18$ & $\begin{array}{c}4,860 \\
(6.2)\end{array}$ & & $\begin{array}{r}-19.7 \\
(3.3)\end{array}$ & & & .58 \\
\hline
\end{tabular}

DEVELOPING COUNTRIES

\begin{tabular}{|c|c|c|c|}
\hline B-19 & $\begin{array}{r}2,770 \\
(5.7)\end{array}$ & $\begin{array}{c}-1.4 \\
(0.9)\end{array}$ & $\begin{array}{r}-64.3 \\
(0.9)\end{array}$ \\
\hline$B-20$ & $\begin{array}{r}2,700 \\
(6.6)\end{array}$ & & \\
\hline$B-21$ & $\begin{array}{r}2,860 \\
(5.4)\end{array}$ & $\begin{array}{l}-1.9 \\
(1.1)\end{array}$ & \\
\hline
\end{tabular}


Table B-3

Coefficients of OLS Equations for Activity of Manufacturing

Affiliates of U.S. Parts Companies

Dependent Variable: NFASM $_{i j}$ (PARTS)

Independent Variables

\begin{tabular}{|c|c|c|c|c|c|c|c|c|c|}
\hline $\begin{array}{l}\text { Eq. } \\
\text { No. }\end{array}$ & $\begin{array}{c}\mathrm{RGDP}_{1} \\
\left(\begin{array}{c}\mathrm{bil} \\
.\end{array}\right)\end{array}$ & $\operatorname{RGDPC}_{i}$ & $\begin{array}{l}\text { Date }_{1 j} \\
(000)\end{array}$ & $\mathrm{REGI}_{\mathbf{i}}$ & $\mathrm{LDC}_{\boldsymbol{i}}$ & ANFAS $_{i}$ & $\overline{\mathrm{R}}$ & $\begin{array}{l}\text { No. } \\
\text { Obs. }\end{array}$ & $\underline{F}$ \\
\hline \multicolumn{10}{|c|}{ ALL COUNTRIES } \\
\hline$B-22$ & $\begin{array}{c}163 \\
(1.6)\end{array}$ & $\begin{array}{r}4.38 \\
(0.6)\end{array}$ & $\begin{array}{l}42.5 \\
(0.0)\end{array}$ & $\begin{array}{l}17.43 \\
(1.0)\end{array}$ & $\begin{array}{r}-6,646 \\
(0.3)\end{array}$ & $\begin{array}{r}-1.90 \\
(0.3)\end{array}$ & .05 & 78 & 1.7 \\
\hline$B-23$ & $\begin{array}{c}176 \\
(3.0)\end{array}$ & & & & & & .09 & & 8.7 \\
\hline B-24 & & & $\begin{array}{l}1.64 \\
(0.2)\end{array}$ & $\begin{array}{r}-19.97 \\
(1.2)\end{array}$ & $\begin{array}{r}-20.358 \\
(1.2)\end{array}$ & $\begin{array}{r}6.01 \\
(1.6)\end{array}$ & .04 & & 1.8 \\
\hline
\end{tabular}

EUROPE

\begin{tabular}{|c|c|c|c|c|c|c|c|c|}
\hline$B-25$ & $\begin{array}{c}187 \\
(1.1)\end{array}$ & & & $\begin{array}{l}26.78 \\
(1.0)\end{array}$ & $\begin{array}{l}-3.24 \\
(0.4)\end{array}$ & .03 & 44 & 1.5 \\
\hline$B-26$ & $\begin{array}{c}176 \\
(1.1)\end{array}$ & $\begin{array}{r}5.34 \\
(0.3)\end{array}$ & & $\begin{array}{l}29.57 \\
(1.1)\end{array}$ & $\begin{array}{l}-3.47 \\
(0.4)\end{array}$ & .01 & & 1.1 \\
\hline$B-27$ & $\begin{array}{l}180 \\
(1.1)\end{array}$ & & $\begin{array}{r}262.8 \\
(0.2)\end{array}$ & $\begin{array}{l}29.00 \\
(1.0)\end{array}$ & $\begin{array}{r}-2.77 \\
(0.3)\end{array}$ & .01 & & 1.1 \\
\hline B-28 & $\begin{array}{l}179 \\
(1.8)\end{array}$ & & & & & .05 & & 3.4 \\
\hline B-29 & & & $\begin{array}{c}-.32 \\
(0.2)\end{array}$ & & $\begin{array}{r}5.49 \\
(1.1)\end{array}$ & -.02 & & 0.6 \\
\hline$B-30$ & & & $\begin{array}{r}5.43 \\
(0.4)\end{array}$ & $\begin{array}{l}39.39 \\
(1.4)\end{array}$ & $\begin{array}{r}3.92 \\
(0.7)\end{array}$ & .00 & & 1.1 \\
\hline
\end{tabular}


Table B-3 (cont.)

Coefficients of OLS Equations for Activity of Manufacturing

Affillates of U.S. Parts Companies

Dependent Variable: NFASM $_{1 j}$ (PARTS)

\section{Independent Variables}

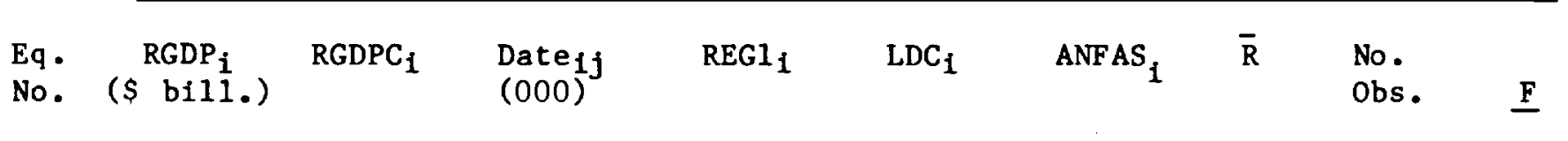

DEVELOPING COUNTRIES

\begin{tabular}{|c|c|c|c|c|c|c|c|}
\hline B-31 & $\begin{array}{c}-193 \\
(1.7)\end{array}$ & & & $\begin{array}{l}16.76 \\
(1.3)\end{array}$ & $\begin{array}{l}26.1 \\
(2.8)\end{array}$ & .32 & 4.4 \\
\hline$B-32$ & $\begin{array}{l}-194 \\
(1.6)\end{array}$ & $\begin{array}{l}-.154 \\
(0.0)\end{array}$ & & $\begin{array}{l}16.95 \\
(1.1)\end{array}$ & $\begin{array}{l}26.1 \\
(2.7)\end{array}$ & .28 & 3.1 \\
\hline B-33 & $\begin{array}{l}-210 \\
(2.0)\end{array}$ & & $\begin{array}{l}-1.20 \\
(1.9)\end{array}$ & $\begin{array}{l}96.25 \\
(0.8)\end{array}$ & $\begin{array}{l}25.8 \\
(2.9)\end{array}$ & .40 & 4.6 \\
\hline$B-34$ & $\begin{array}{c}80 \\
(1.2)\end{array}$ & & & $\begin{array}{l}38.03 \\
(0.3)\end{array}$ & & .08 & 2.0 \\
\hline$B-35$ & $\begin{array}{c}93 \\
(2.0)\end{array}$ & & & & & .12 & 4.0 \\
\hline$B-36$ & & & & & $\begin{array}{l}13.0 \\
(3.1)\end{array}$ & .28 & 9.6 \\
\hline$B-37$ & & & $\begin{array}{l}-0.96 \\
(1.6)\end{array}$ & & $\begin{array}{l}10.2 \\
(2.3)\end{array}$ & .33 & 6.5 \\
\hline
\end{tabular}


Table C-1

Coefficients of TOBIT Equations for Activity of Manufacturing Affiliates of U.S. Auto Companies

\begin{tabular}{|c|c|c|c|c|c|c|c|}
\hline \multirow[b]{2}{*}{$\begin{array}{l}\text { Eq. } \\
\text { No. }\end{array}$} & \multicolumn{6}{|c|}{ Independent Variables } & \multirow[b]{2}{*}{$\begin{array}{l}\text { No. } \\
\text { Obs. }\end{array}$} \\
\hline & $\begin{array}{l}\text { Dependent } \\
\text { Variable }\end{array}$ & $\mathrm{RGDP}_{\mathbf{i}}$ & LNGDP $_{i}$ & $\mathrm{RGDPC}_{i}$ & $\mathrm{LDC}_{i}$ & $\mathrm{REGl}_{1}$ & \\
\hline & \multicolumn{7}{|c|}{ ALL COUNTRIES } \\
\hline$C-1$ & $\overline{\text { NFASM }_{i j}}$ & $\begin{array}{l}33.7 \\
(4.2)\end{array}$ & & & $\begin{array}{l}-.515 \\
(2.5)\end{array}$ & $\begin{array}{l}1.28 \\
(6.4)\end{array}$ & $\begin{array}{r}468 \\
45 \text { non-limit }\end{array}$ \\
\hline$C-2$ & & $\begin{array}{l}28.6 \\
(3.5)\end{array}$ & & $\begin{array}{l}.222 \\
(3.2)\end{array}$ & $\begin{array}{l}.040 \\
(0.1)\end{array}$ & $\begin{array}{l}1.42 \\
(6.6)\end{array}$ & 468 \\
\hline$C-3$ & & $\begin{array}{l}28.5 \\
(3.5)\end{array}$ & & $\begin{array}{l}.216 \\
(3.9)\end{array}$ & & $\begin{array}{r}1.41 \\
(6.6)\end{array}$ & 468 \\
\hline \multirow[t]{2}{*}{$c-4$} & & & $(3.4)$ & $\begin{array}{r}.189 \\
(3.2)\end{array}$ & & $\begin{array}{l}1.11 \\
(4.6)\end{array}$ & \\
\hline & \multicolumn{6}{|c|}{ EUROPE } & \\
\hline$c-5$ & & $\begin{array}{l}55.5 \\
(3.9)\end{array}$ & & & & $\begin{array}{r}.71 \\
(2.0)\end{array}$ & $\begin{array}{l}84 \\
14 \text { non-1imit }\end{array}$ \\
\hline$c-6$ & & $\begin{array}{l}63.8 \\
(3.6)\end{array}$ & & $\begin{array}{l}-.126 \\
(0.8)\end{array}$ & & $(1.54$ & 84 \\
\hline \multirow[t]{2}{*}{$C-7$} & & & $\begin{array}{l}.58 \\
(2.8)\end{array}$ & $\begin{array}{l}-.66 \\
(0.4)\end{array}$ & & $\begin{array}{l}.44 \\
(1.0)\end{array}$ & 84 \\
\hline & \multicolumn{6}{|c|}{ DEVELOPING COUNTRIES } & \\
\hline$c-8$ & & $\begin{array}{l}45.9 \\
(2.5)\end{array}$ & & & & $\begin{array}{l}1.45 \\
(4.9)\end{array}$ & $\begin{array}{r}368 \\
24 \text { non-limit }\end{array}$ \\
\hline$c-9$ & & $\begin{array}{l}51.1 \\
(2.7)\end{array}$ & & $\begin{array}{l}.280 \\
(3.3)\end{array}$ & & $\begin{array}{l}1.5 \\
(4.7)\end{array}$ & 368 \\
\hline$c-10$ & & & $\begin{array}{l}.345 \\
(2.5)\end{array}$ & $\begin{array}{l}.225 \\
(2.5)\end{array}$ & & $\begin{array}{c}1.2 \\
(3.3)\end{array}$ & 368 \\
\hline
\end{tabular}




$$
\begin{gathered}
-64- \\
\text { Table C-2 }
\end{gathered}
$$

Coefficients of TOBIT Equations for Activity of All Auto Affiliates of U.S. Auto Companies

\begin{tabular}{|c|c|c|c|c|c|c|c|}
\hline \multirow[b]{2}{*}{$\mathrm{Eq}$. } & \multirow[b]{2}{*}{ Dependent } & \multicolumn{5}{|c|}{ Independent Variables } & \multirow[b]{2}{*}{ No. } \\
\hline & & $\mathrm{RGDP}_{\mathbf{i}}$ & $\mathrm{LNGDP}_{\mathbf{i}}$ & $\mathrm{RGDPC}_{i}$ & $\mathrm{LDC}_{\mathfrak{1}}$ & $\mathrm{REGl}_{1}$ & \\
\hline No. & Variable & & ALL & UNTRIES & & & obs. \\
\hline$C-11$ & $\mathrm{NFAS}_{i j}$ & $\begin{array}{l}34.2 \\
(5.0)\end{array}$ & & & $\begin{array}{l}-1.07 \\
(6.6)\end{array}$ & $\begin{array}{l}.674 \\
(4.3)\end{array}$ & $\begin{array}{r}468 \\
83 \text { non-limit }\end{array}$ \\
\hline$C-12$ & & $\begin{array}{l}29.3 \\
(4.2)\end{array}$ & & $\begin{array}{l}.266 \\
(4.9)\end{array}$ & $\begin{array}{r}-.30 \\
(1.3)\end{array}$ & $\begin{array}{l}.849 \\
(5.0)\end{array}$ & 468 \\
\hline$c-13$ & & & $\begin{array}{l}.305 \\
(5.2)\end{array}$ & & $\begin{array}{l}-.90 \\
(5.3)\end{array}$ & $\begin{array}{l}.304 \\
(1.7)\end{array}$ & 468 \\
\hline$c-14$ & & $\begin{array}{l}36.1 \\
(5.2)\end{array}$ & & $\begin{array}{l}.203 \\
(4.0)\end{array}$ & $\begin{array}{l}-.39 \\
(1.8)\end{array}$ & & 468 \\
\hline$c-15$ & & & $\begin{array}{l}.325 \\
(6.1)\end{array}$ & $\begin{array}{l}.163 \\
(3.1)\end{array}$ & $\begin{array}{l}-.37 \\
(1.6)\end{array}$ & & 468 \\
\hline$C-16$ & $\operatorname{NLFAS}_{i j}$ & $\begin{array}{l}31.8 \\
(4.6)\end{array}$ & & & $\begin{array}{l}-1.04 \\
(6.3)\end{array}$ & $\begin{array}{l}.854 \\
(5.3)\end{array}$ & 468 \\
\hline $\mathrm{C}-17$ & & & $\begin{array}{l}.349 \\
(5.5)\end{array}$ & & $\begin{array}{r}0.84 \\
(4.7)\end{array}$ & $\begin{array}{l}.443 \\
(2.5)\end{array}$ & 468 \\
\hline$c-18$ & & & $\begin{array}{l}.294 \\
(4.4)\end{array}$ & $\begin{array}{l}.254 \\
(5.4)\end{array}$ & & $\begin{array}{l}.698 \\
(3.5)\end{array}$ & 468 \\
\hline
\end{tabular}

Independent Variables 
Table C-2 (cont.)

Independent Variables

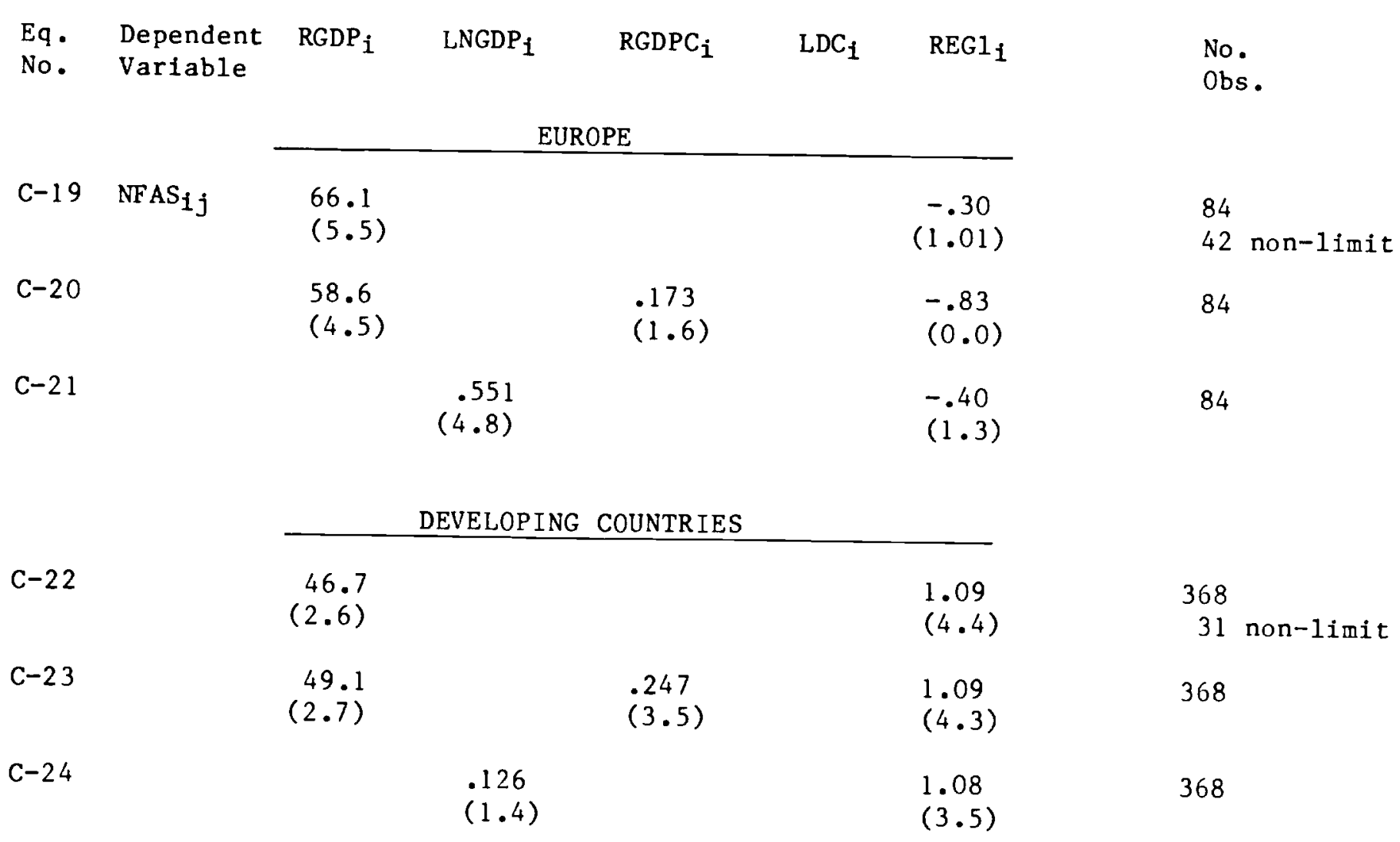

